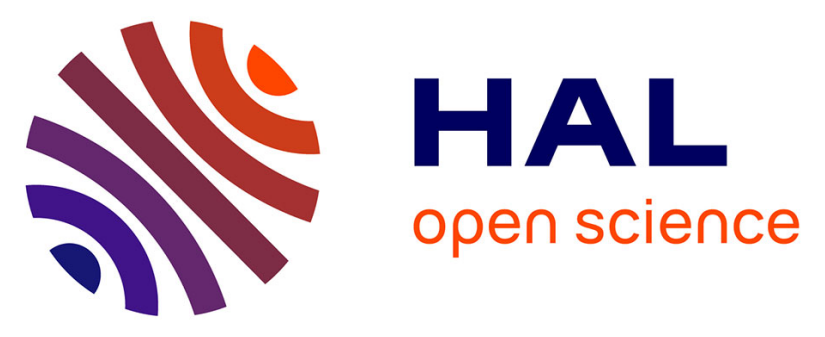

\title{
Multireversible Redox Processes in a Self-Assembled Nickel Pentanuclear Bis(Triple-stranded Helicate): Structural and Spectroscopic Characterizations in the Ni II 5 and Ni I Ni II 4 Redox States
}

Eric Gouré, Bertrand Gerey, Jacques Pécaut, Fabrice Thomas, Jérôme Fortage, Marie-noëlle Collomb

\section{To cite this version:}

Eric Gouré, Bertrand Gerey, Jacques Pécaut, Fabrice Thomas, Jérôme Fortage, et al.. Multireversible Redox Processes in a Self-Assembled Nickel Pentanuclear Bis(Triple-stranded Helicate): Structural and Spectroscopic Characterizations in the Ni II 5 and Ni I Ni II 4 Redox States. ChemElectroChem, 2021, 8 (15), pp.2912-2920. 10.1002/celc.202100895 . hal-03423066

\section{HAL Id: hal-03423066 https://hal.science/hal-03423066}

Submitted on 9 Nov 2021

HAL is a multi-disciplinary open access archive for the deposit and dissemination of scientific research documents, whether they are published or not. The documents may come from teaching and research institutions in France or abroad, or from public or private research centers.
L'archive ouverte pluridisciplinaire HAL, est destinée au dépôt et à la diffusion de documents scientifiques de niveau recherche, publiés ou non, émanant des établissements d'enseignement et de recherche français ou étrangers, des laboratoires publics ou privés. 


\title{
Multireversible redox processes in a self-assembled nickel
} pentanuclear bis(triple-stranded helicate): structural and spectroscopic characterizations in the $\mathrm{Ni}_{5}$ and $\mathrm{Ni}^{\prime} \mathrm{Ni}_{4}$ states

\author{
Eric Gouré ${ }^{[a]}$ Bertrand Gerey, ${ }^{[a]}$ Jacques Pécaut, ${ }^{[b]}$ Fabrice Thomas, ${ }^{[a]}$ Jérôme Fortage ${ }^{[a]}$ and Marie- \\ Noëlle Collomb*[a]
}

Dedicated to the memory of Professor Jean-Michel Savéant

[a] Dr. E. Gouré, Dr. B. Gerey, Pr. F. Thomas, Dr. J. Fortage, Dr. M.-N. Collomb,
Univ. Grenoble Alpes, DCM, CNRS, DCM, 38000 Grenoble, France
E-mail: marie-noelle.collomb@univ-grenoble-alpes.fr
Dr. J. Pécaut
Univ. Grenoble Alpes, CEA, CNRS, IRIG, SyMMES, 38000 Grenoble, France

Supporting information for this article is given via a link at the end of the document.

\begin{abstract}
We previously reported the multireversible redox behavior of the bis(triple-helicate) pentanuclear complexes of the type $[\{\mathrm{M}(\mu-$ bpp $\left.\left.)_{3}\right\}_{2} \mathrm{M}\left(\mu_{3}-\mathrm{X}\right)\right]^{\mathrm{n}+}(\mathrm{M}=\mathrm{Mn}$, Fe with $\mathrm{X}=\mathrm{O}$ and Co with $\mathrm{X}=\mathrm{OH})$ with the rigid tetradentate binucleating 3,5-bis (pyridine-2-yl)pyrazole (bpp-) ligand. In this article, we focus on the nickel derivative of this family, $\left[\left\{\mathrm{Ni}^{\prime \prime}(\mu \text {-bpp })_{3}\right\}_{2} \mathrm{Ni}_{3}(\mu-\mathrm{OH})\right]^{3+}\left(\mathbf{1}^{3+}\right)$, which exhibits up to five reversible or quasi-reversible one-electron waves in $\mathrm{CH}_{3} \mathrm{CN}$ solution. The two one-electron oxidized species as well as the one-electron reduced species, with a respective $4 \mathrm{Ni}^{\prime \prime} 1 \mathrm{Ni}^{\prime \prime \prime}\left(\mathbf{1}^{4+}\right)$, $3 \mathrm{Ni}^{i l} 2 \mathrm{Ni}^{\prime \prime \prime}\left(\mathbf{1}^{5+}\right)$ and $1 \mathrm{Ni}{ }^{\prime} 4 \mathrm{Ni}{ }^{\prime \prime}$ $\left(1^{2+}\right)$ composition, were quantitatively generated by bulk electrolyses and spectroscopically characterized, highlighting the high stability of this family of complexes in several redox states. In addition to the initial complex $\mathbf{1}^{3+}$, the mixed-valence $\mathbf{1}^{2+}$ was also successfully characterized by single-crystal $\mathrm{X}$-ray diffraction, allowing to locate the sites of the successive reversible one-electron events. $1^{2+}$ is an unusual example of a multinuclear complex including the low-valent $\mathrm{Ni}(\mathrm{I})$ state.
\end{abstract}

\section{Introduction}

Polynuclear transition-metal complexes have been intensively studied over the last few decades owing to their potential applications in various fields such as supramolecular chemistry, molecular magnetism, catalysis or even bioinorganic chemistry for their relevance as models to the active site of metalloenzymes..$^{[1-15]}$ The geometry and nuclearity of the multinuclear complexes can be controlled, although to some extend, by the judiscious choice of the ligand in terms of rigidity, number and orientation of the coordination sites and nature of donor atoms. ${ }^{[16-17]}$ Among the various multidentate ligands explored, those involving a pyrazole motif or similar derivatives have been extensively used to afford polynuclear complexes, the two adjacent $\mathrm{N}$ donors acting as a bridge between two metal centers. ${ }^{[18-22]}$ In addition to maintaining the metal centers in close proximity, such derivatives allow an electronic communication between them leading to specific properties. The rigid tetradentate binucleating 3,5-bis(pyridine-2-yl)pyrazole ligand (Hbpp) is an attractive ligand of this family. ${ }^{[23]}$ Used alone or in combination with an additional ancillary ligand, the Hbpp ligand has lead to the isolation of various homo- and hetero-bimetallic complexes with several transition metal ions $\left(\mathrm{Ru}^{2+}, \mathrm{Ni}^{2+}, \mathrm{Cu}^{2+}\right.$,
$\left.\mathrm{Fe}^{2+}, \mathrm{Co}^{2+}, \mathrm{Mn}^{2+}, \mathrm{Cr}^{3+}, \mathrm{Ln}^{3+}, \mathrm{Zn}^{2+}\right)$. If dinuclear are the most common compounds, ${ }^{[21,24-46]}$ few examples of tri-,${ }^{[47]}$ tetra- ${ }^{[48]}$ and pentanuclear have been described as well. The pentanuclear complexes, synthetized at high temperature by reacting the deprotonated bpp- ligand with the first-row transition metal ion $\mathrm{Fe}^{2+}, \mathrm{Mn}^{2+}, \mathrm{Ni}^{2+}, \mathrm{Cu}^{2+}, \mathrm{Zn}^{2+}$ or $\mathrm{Co}^{2+}$, feature a remarkable bis(triple-helical) architecture in which the five metal ions are arranged in a trigonal bipyramidal topology with two axial $\{\mathrm{M}(\mu-$ bpp $\left.)_{3}\right\}$ units connecting a central $\mu_{3}$-oxo or hydroxo trinuclear core $\left\{\mathrm{M}_{3}\left(\mu_{3}-\mathrm{X}\right)\right\}(\mathrm{X}=\mathrm{O}$ or $\mathrm{OH})($ Scheme 1$) \cdot{ }^{[49-54]}$

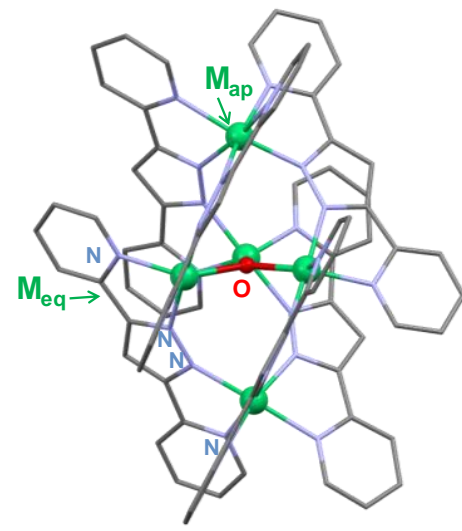

$\left[\left\{\mathrm{M}_{2}{ }_{2}(\mu-\mathrm{L})_{3}\right\}_{2} \mathrm{M}_{2}{ }_{2} \mathrm{M}^{\prime \prime \prime}\left(\mu_{3}-\mathrm{O}\right)\right]^{3+}$ for $\mathrm{M}=\mathrm{Mn}, \mathrm{Fe}$ $\left[\left\{\mathrm{M}_{2}{ }_{2}(\mu-\mathrm{L})_{3}\right\}_{2} \mathrm{M}_{3} \|_{3}\left(\mu_{3}-\mathrm{OH}\right)\right]^{3+}$ for $\mathrm{M}=\mathrm{Co}, \mathrm{Ni}\left(1^{3+}\right)$

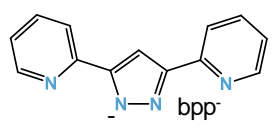

Scheme 1. Schematic representation of the molecular structure of the $[\{\mathrm{M}(\mu-$ bpp $\left.\left.)_{3}\right\}_{2} \mathrm{M}_{3}\left(\mu_{3}-\mathrm{X}\right)\right]^{\mathrm{n}+}$ complexes $\left(\mathrm{M}_{\mathrm{ap}}\right.$ and $\mathrm{M}_{\text {eq }}$ refer to metal $\mathrm{M}$ located in apical and in equatorial position, respectively) and of the deprotonated bpp- ligand.

These complexes, namely $\left[\left\{\mathrm{M}(\mu-\mathrm{bpp})_{3}\right\}_{2} \mathrm{M}_{3}\left(\mu_{3}-\mathrm{X}\right)\right]^{n+}(\mathrm{M}=\mathrm{Mn}$ or $\mathrm{Fe}$ with $\mathrm{X}=\mathrm{O}$, and $\mathrm{M}=\mathrm{Cu}, \mathrm{Ni}$, Co or $\mathrm{Zn}$ with $\mathrm{X}=\mathrm{OH}$ ), are very stable and present interesting structure-specific physicochemical and catalytic properties. ${ }^{[50,55]}$ In fact, the iron derivative $\left[\left\{\mathrm{Fe}^{\prime \prime}(\mu-\right.\right.$ bpp $\left.\left.)_{3}\right\} \mathrm{Fe}{ }_{3}\left(\mu_{3}-\mathrm{O}\right)\right]^{2+}$ has been proposed by the group of Masaoka to be an active catalyst for the electrocatalytic water oxidation 
thanks to its ability to accumulate four oxidative equivalents, the four-electron oxidized species, Fe ${ }^{\prime \prime \prime}{ }_{5}$, being reactive with $\mathrm{H}_{2} \mathrm{O}$ to generate $\mathrm{O}_{2} \cdot{ }^{[55-58]}$ The molecular nature of the active catalytic species has been however recently questioned. ${ }^{[59-60]}$ More recently, the same group also shown that the cobalt derivative, $\left[\left\{\mathrm{Co} "(\mu \text {-bpp })_{3}\right\} \mathrm{Co}_{3}{ }_{3}\left(\mu_{3}-\mathrm{OH}\right)\right]^{3+}$, upon reduction, can act as a catalyst for $\mathrm{CO}_{2}$ reduction into $\mathrm{CO}^{[53]}$ Another interesting characteristic of these electronically coupled pentanuclear compounds is their electrochemical behavior. We indeed demonstrated for the manganese and the iron derivatives [ $\left[\mathrm{M}^{\prime \prime}(\mu\right.$ bpp) $\left.\left.{ }_{3}\right\} \mathrm{M}_{2}{ }_{2} \mathrm{M}^{\mathrm{III}}\left(\mu_{3}-\mathrm{O}\right)\right]^{3+}(\mathrm{M}=\mathrm{Mn}, \mathrm{Fe})$ that the electronically coupled five metal ions confer to the architecture multistable redox states with the detection of five successive reversible metal-centered

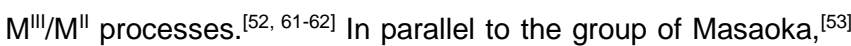
we also isolated and characterized the cobalt derivative, [\{Co" $(\mu$ bpp $\left.\left.)_{3}\right\}_{2} \mathrm{Co}_{3}{ }_{3}\left(\mu_{3}-\mathrm{OH}\right)\right]^{3+}$, and shown that this complex exhibits up to seven successive reversible metal-centered redox processes and hence is capable to stabilizing eight consecutive redox states from $\mathrm{Co}_{5}{ }_{5}$ to $\mathrm{CO}_{3}{ }_{3} \mathrm{Co}{ }^{111}{ }_{2 .}{ }^{[54]}$ Furthermore, several mixed-valence states of these complexes were successfully generated by bulk electrolyses allowing their characterization by spectroscopy and for some of them, by X-ray crystallography. ${ }^{[52,54,56,61]}$ For instance in addition to species including ions in high-valent $\mathrm{M}(\mathrm{III})$ oxidation state, such as $\left[\left\{\mathrm{Mn}^{\prime \prime}(\mu \text {-bpp })_{3}\right\}_{2} \mathrm{Mn}_{2}{ }_{2} \mathrm{Mn}^{\prime \prime \prime}\left(\mu_{3}-\mathrm{O}\right)\right]^{3+}$ and $\left[\left\{\mathrm{Co}^{\prime \prime}(\mu-\right.\right.$ bpp $\left.\left.)_{3}\right\}_{2} \mathrm{Co}^{\prime \prime} \mathrm{Co}^{\prime \prime \prime}{ }_{2}\left(\mu_{3}-\mathrm{OH}\right)\right]^{5+}$, we succeeded to structurally characterized the $\left[\left\{\mathrm{Co}{ }^{\prime \prime}(\mu \text {-bpp })_{3}\right\}_{2} \mathrm{Co}^{\prime} \mathrm{Co}_{2}{ }_{2}\left(\mu_{3}-\mathrm{OH}\right)\right]^{2+}$ species, an unusual example of a multinuclear complex including the lowvalent $\mathrm{Co}(\mathrm{I})$ state..$^{[52,54]}$

In this context, the aim of the present work was to extend our studies to the still unexplored electrochemical properties of the nickel member of the pentanuclear bis(triple-helical) complex family. Because of the electronic configuration of the $\mathrm{Ni}$ ion which gives access to the following three oxidation states, $+\mathrm{I},+\mathrm{Il}$, and + III, this complex, like the cobalt equivalent, can lead to an interesting redox behavior in this pentanuclear architecture. The $\left[\left\{\mathrm{Ni}^{\prime \prime}(\mu \text {-bpp })_{3}\right\}_{2} \mathrm{Ni}_{3}\left(\mu_{3}-\mathrm{OH}\right)\right](\mathrm{SCN})_{3}$ complex was previously isolated by the group of $\mathrm{Li}^{[51]}$ and its magnetic properties investigated. In this article, we describe the preparation of this compound as $\mathrm{BF}_{4}^{-}$salt using another synthetic way to avoid the electroactive SCN counterions. Cyclic voltammetry and bulk electrolysis are used to establish the stability of the pentanuclear structure in solution in several redox states and the electrogenerated species are characterized by UV-visible and electron paramagnetic resonance (EPR) spectroscopy. In addition, the structures of the initial complex $\left[\left\{\mathrm{Ni}^{\mathrm{I}}(\mu-\right.\right.$ bpp $\left.\left.)_{3}\right\}_{2} \mathrm{Ni}_{3}\left(\mu_{3}-\mathrm{OH}\right)\right]^{3+}\left(\mathbf{1}^{3+}\right)$ and of the one-electron reduced form electrochemically generated, $\left[\left\{\mathrm{Ni}^{\prime \prime}(\mu \text {-bpp })_{3}\right\}_{2} \mathrm{Ni}^{\prime} \mathrm{Ni}_{2}\left(\mu_{3}-\mathrm{OH}\right)\right]^{2+}\left(\mathbf{1}^{2+}\right)$, successfully characterized by single-crystal $\mathrm{X}$-ray diffraction, are also discussed. Finally, the electrochemical behavior of $\mathbf{1}^{3+}$ is compared with those of the previously examined pentanuclears of $\mathrm{Mn}, \mathrm{Fe}, \mathrm{Zn}$ and $\mathrm{Co}$.

\section{Results and Discussion}

\subsection{Synthesis and crystals structures of the complexes}

To synthesize $\left[\left\{\mathrm{Ni}^{\prime \prime}(\mu-\mathrm{bpp})_{3}\right\}_{2} \mathrm{Ni}_{3}\left(\mu_{3}-\mathrm{OH}\right)\right]^{3+}\left(\mathbf{1}^{3+}\right)$, we employed a procedure similar to the one we previously used for the analogous derivatives, $\left[\left\{\mathrm{M}^{\prime \prime}(\mu-\mathrm{bpp})_{3}\right\}_{2} \mathrm{M}_{2}{ }_{2} \mathrm{M}^{\prime \prime \prime}\left(\mu_{3}-\mathrm{O}\right)\right]^{3+}(\mathrm{M}=\mathrm{Mn}$ or $\mathrm{Fe})$ and
[\{Co" $\left.\left.(\mu \text {-bpp })_{3}\right\}_{2} \mathrm{Co}_{3}{ }_{3}\left(\mu_{3}-\mathrm{OH}\right)\right]^{3+}{ }^{[52,54,61]}$ This procedure consists in refluxing at $120^{\circ} \mathrm{C}$ for 3 days an acetonitrile solution containing the $\mathrm{Hbpp}$ ligand and the nickel salt $\mathrm{Ni}\left(\mathrm{BF}_{4}\right)_{2} \cdot 6 \mathrm{H}_{2} \mathrm{O}$ in a molar ratio 6:5 under aerobic conditions. $\mathrm{Et}_{3} \mathrm{~N}$ was also added to the mixture in order to deprotonate the ligand. Green crystals of the [ $\left[\mathrm{Ni}^{\prime \prime}(\mu-\right.$ bpp $\left.\left.)_{3}\right\}_{2} \mathrm{Ni}_{3}\left(\mu_{3}-\mathrm{OH}\right)\right]\left(\mathrm{BF}_{4}\right)_{3}\left(\mathbf{1}_{(}\left(\mathrm{BF}_{4}\right)_{3}\right)$, were obtained with a high yield after slow diffusion of diethyl ether into the acetonitrile solution of the complex. This procedure differs from the one previously used by $\mathrm{Li}$ and co-workers for the synthesis of [ $\left[\mathrm{Ni}^{\prime \prime}(\mu-\right.$ bpp $\left.\left.)_{3}\right\}_{2} \mathrm{Ni}_{3}\left(\mu_{3}-\mathrm{OH}\right)\right](\mathrm{SCN})_{3}$ which consists in reacting $\mathrm{NiSO}_{4} \cdot 6 \mathrm{H}_{2} \mathrm{O}$, $\mathrm{Hbpp}$ and NaSCN hydrothermally in aqueous ammonia at $160^{\circ} \mathrm{C}$ for $72 h .^{[51]}$

We also succeeded in the isolation of the one-electron reduced form, $\quad\left[\left\{\mathrm{Ni}^{\prime \prime}(\mu-\mathrm{bpp})_{3}\right\}_{2} \mathrm{Ni}^{\prime} \mathrm{Ni}_{2}{ }_{2}\left(\mu_{3}-\mathrm{OH}\right)\right]^{2+} \quad\left(\mathbf{1}^{2+}\right), \quad$ following an electrochemical reduction of $1^{3+}$ at $-1.7 \mathrm{~V}$ vs $\mathrm{Ag} / \mathrm{AgNO}_{3}$ (preparative electrolysis) under anaerobic conditions (see below and Experimental Section). Single crystals of $\left[\left\{\mathrm{Ni}^{\prime \prime}(\mu-\right.\right.$ bpp $\left.\left.)_{3}\right\}_{2} \mathrm{Ni}^{\prime} \mathrm{Ni}_{2}{ }_{2}\left(\mu_{3}-\mathrm{OH}\right)\right]\left(\mathrm{ClO}_{4}\right)_{2} \cdot 2.5 \mathrm{CH}_{3} \mathrm{CN} \quad\left(\mathbf{1}\left(\mathrm{ClO}_{4}\right)_{2} \cdot 2.5 \mathrm{CH}_{3} \mathrm{CN}\right)$ suitable for $\mathrm{X}$-ray crystallography characterization were grown by slow diffusion of diethyl ether into the electrogenerated $\mathrm{CH}_{3} \mathrm{CN}$ solution of the complex which contains $0.1 \mathrm{M}$ of $\left[\mathrm{Bu}_{4} \mathrm{~N}\right] \mathrm{ClO}_{4}$ as supporting electrolyte (see below). In order to compare the structures of $\mathbf{1}^{2+}$ and $\mathbf{1}^{3+}$, we also crystallized the $\mathbf{1}^{3+}$ complex with perchlorate salt. $\mathbf{1}\left(\mathrm{ClO}_{4}\right)_{2} \cdot 2 \mathrm{CH}_{3} \mathrm{CN}$ and $\left[\left\{\mathrm{Ni}^{\prime \prime}(\mu \text {-bpp })_{3}\right\}_{2} \mathrm{Ni}_{3}\left(\mu_{3}{ }^{-}\right.\right.$ $\mathrm{OH})]\left(\mathrm{ClO}_{4}\right)_{3} \cdot 1.5 \mathrm{CH}_{3} \mathrm{CN} \cdot\left(\mathrm{CH}_{3} \mathrm{CH}_{2}\right)_{2} \mathrm{O}$

$\left(1\left(\mathrm{ClO}_{4}\right)_{3} \cdot 1.5 \mathrm{CH}_{3} \mathrm{CN} \cdot\left(\mathrm{CH}_{3} \mathrm{CH}_{2}\right)_{2} \mathrm{O}\right)$ crystallize in the monoclinic $C 2 / C$ and $P 2_{1} / n$ space group, respectively. The crystallographic data and structure refinement details of the complexes are given in Table S1, and selected bond distances and angles are given in Tables S2 and S3. Figure 1 displays the thermal ellipsoid plots obtained from the crystallographic structures. Similarly to the related $\left[\left\{\mathrm{M}^{\prime \prime}(\mu \text {-bpp })_{3}\right\}_{2} \mathrm{M}_{3}{ }_{3}\left(\mu_{3}-\mathrm{OH}\right)\right]^{3+}$ and $\left[\left\{\mathrm{M}^{\prime \prime}(\mu-\mathrm{bpp})_{3}\right\}_{2} \mathrm{M}_{3}{ }_{3}\left(\mu_{3^{-}}\right.\right.$ O) $]^{4+}$ complexes $(\mathrm{M}=\mathrm{Fe}, \mathrm{Mn}, \mathrm{Co}, \mathrm{Zn}, \mathrm{Cu}),{ }^{[49-54]}$ each cation features a bis(triple-stranded helicate) configuration, with a pair of enantiomers being present in each crystal. On the basis of the charge of the cations and to the presence of a protonated $\mu_{3}$-oxo bridge, oxidation states of the nickel ions in $1^{3+}$ and $1^{2+}$ can be assigned as $\mathrm{Ni}_{5}{ }_{5}$ and $\mathrm{Ni}^{\prime} \mathrm{Ni}_{4}{ }_{4}$, respectively. For both complexes, the three $\mathrm{Ni}$ ions located in the central core are penta-coordinated to one oxygen of the hydroxo ion and four nitrogen atoms from two bpp- ligands in a distorted $\mathrm{N}_{4} \mathrm{O}$ trigonal bipyramid coordination environment. A distorted octahedral geometry is observed for the two apical $\mathrm{Ni}$ ions coordinated to six nitrogen atoms from three bpp- ligands. Each tetradentate bpp- ligand is coordinated to one apical and one equatorial $\mathrm{Ni}$ ion through one $\mathrm{N}$-pyridine and one $\mathrm{N}$-pyrazolyl, and thus acting as a bridge between the axial and equatorial metal site. The $\mathrm{X}$-ray features of $\mathbf{1}^{3+}$ are similar to those published for $\left[\left\{\mathrm{Ni}^{\prime \prime}(\mu-\mathrm{bpp})_{3}\right\}_{2} \mathrm{Ni}_{3}\left(\mu_{3}-\mathrm{OH}\right)\right](\mathrm{SCN})_{3} .{ }^{[51]}$ Unlike the tricationic $1^{3+}$ complex, the $1^{2+}$ cation adopts a two-fold symmetric structure with a $\mathrm{C} 2$-axis passing through one $\mathrm{Ni}$ of the central core, namely $\mathrm{Ni}(1)$, and the $\mu_{3}-\mathrm{OH}$ ion. The apical metal-ligand bond distances $\left(\mathrm{Ni}_{\mathrm{ap}}-\mathrm{N}\right.$, Figure 1) are very similar for both complexes (Ni(3), av. 2.11(5) $\AA$ for $1^{2+} ; \mathrm{Ni}(4)$, av. 2.10(5) and $\mathrm{Ni}(5)$, av. 2.10(4) $\AA$ for $1^{3+}$, Table 1) and consistent with two high-spin Ni(II) ions $(S=1)$. These distances are very similar to that found in binuclear $\mathrm{Ni}(\mathrm{II})$ complexes with bpp and close related ligands. ${ }^{[21}$ $\left.{ }^{27,} 37,63\right]$ As expected for complexes with such ligands, ${ }^{[52]}$ the $\mathrm{Mn}$ $\mathrm{N}$-pyridine distances are also longer than the $\mathrm{Mn}-\mathrm{N}$-pyrazole ones (Tables S2-S3). Regarding the trinuclear central core, the average of the $\mathrm{Ni}_{\text {eq }}-\mathrm{N}, \mathrm{O}$ bond distances in $1^{3+}$, in the range 2.02$2.03 \AA$, are likewise fully consistent with three high-spin $\mathrm{Ni}(\mathrm{II})$ 
(Table 1) ${ }^{[64]}$ In addition, the $\mathrm{Ni}-\mu-\mathrm{OH}$ bond distances, in the range 2.008-2.031 $\AA$, are similar to those found in trinuclear nickel complexes featuring a $\mathrm{Ni}_{3}{ }_{3}\left(\mu_{3}-\mathrm{OH}\right)$ core ${ }^{[65-68]}$ and longer than those of trinuclear compounds with a $\mathrm{Ni}_{3}{ }_{3}\left(\mu_{3}-\mathrm{O}\right)$ core (in the range $1.785-1.803 \AA)^{[69-70]}$ fully consistent with the protonation of the central oxygen.
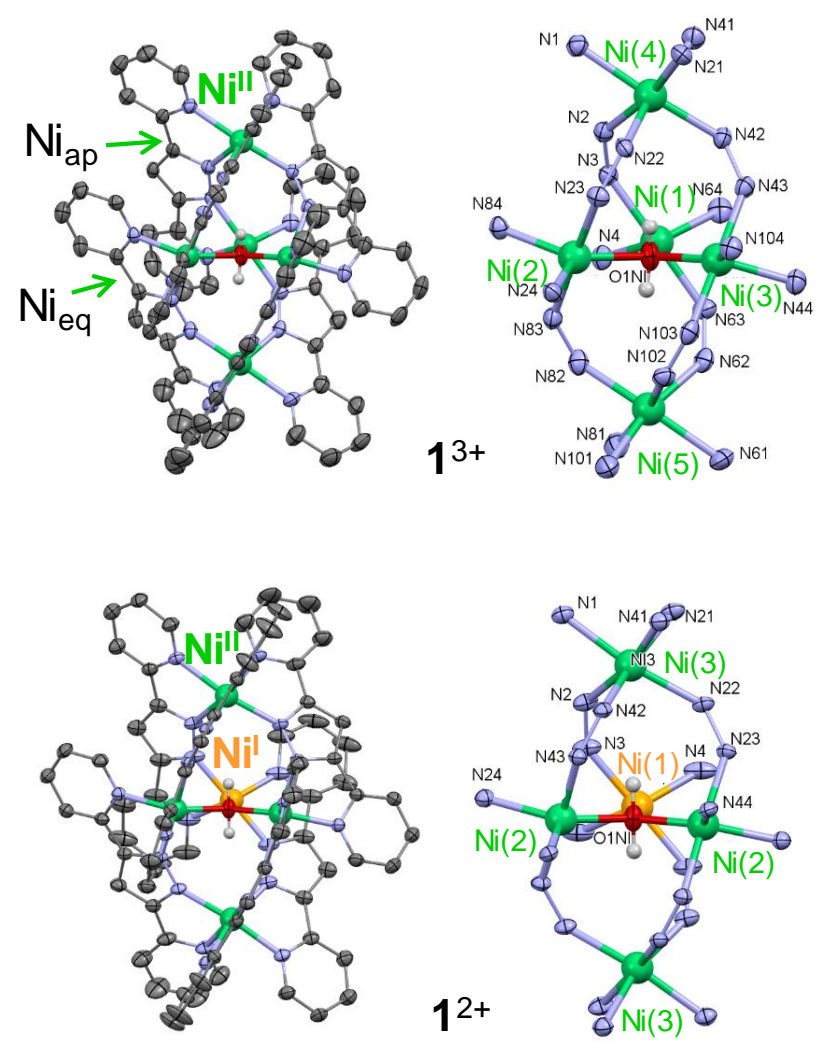

Figure 1. ORTEP representation with $50 \%$ probability thermal of the molecular structure of the $\left[\left\{\mathrm{Ni}^{\prime \prime}(\mu \text {-bpp })_{3}\right\}_{2} \mathrm{Ni}_{3}{ }_{3}\left(\mu_{3}-\mathrm{OH}\right)\right]^{3+}\left(\mathbf{1}^{3+}\right)$ and $\left[\left\{\mathrm{Ni}{ }^{\prime \prime}(\mu \text {-bpp })_{3}\right\}_{2} \mathrm{Ni}^{\prime} \mathrm{Ni}^{\prime \prime}{ }_{2}\left(\mu_{3^{-}}\right.\right.$ $\mathrm{OH})]^{2+}\left(\mathbf{1}^{2+}\right)$ cations. The hydrogen atoms of the bpp ligands have been omitted for clarity. On the right side, the corresponding metallic cores including the first coordination spheres of the metal ions are shown. In both structures, the hydrogen atom of the bridging oxygen is disordered on the two positions on each side of the equatorial plane with a 50/50 occupancy rate.

We can notice that if in $\mathbf{1}^{2+}$ the $\mathrm{Ni}_{\text {eq }}-\mathrm{N}, \mathrm{O}$ distances average are quite similar (in the range 2.00-2.04 $\AA$ ) to those of $1^{3+}$, the $\mathrm{Ni}-\mu$ $\mathrm{OH}$ bond distances in the range 1.9437-2.272 $\AA$ and the $\mathrm{Ni}-(\mu$ $\mathrm{OH})-\mathrm{Ni}$ angles are significantly more dispersed. This larger distortion of the triangular $\mathrm{Ni}_{3}\left(\mu_{3}-\mathrm{OH}\right)$ core observed in $1^{2+}$ compared to $1^{3+}$ (Table 1) along with the presence of $\mathrm{Ni}$ (II) ions in apical positions in $\mathbf{1}^{2+}$ clearly indicates that the reduction of a $\mathrm{Ni}(\mathrm{II})$ ion into a $\mathrm{Ni}(\mathrm{I})$ ion occurs in the central core. Besides, it is difficult to conclude on whatever the $\mathrm{Ni}_{2}{ }^{11} \mathrm{Ni}^{1}$ core of $1^{2+}$ is a localized or delocalized system. The bond distances of $\mathrm{Ni}(1)-\mathrm{O}$ are notably longer than the $\mathrm{Ni}(2)-\mathrm{O}$ suggesting a localized system, but, on the other hand, the average bond distances for each $\mathrm{Ni}$ of the central core are rather similar which is in favor of a delocalized system (Table 2).
Table 1 Comparison of selected $\mathrm{Ni}$ ligand bond lengths (angstroms) and $\mathrm{Ni}$ $\mu(\mathrm{OH})-\mathrm{Ni}$ angles (degrees) for $\left[\left\{\mathrm{Ni}^{\prime \prime}(\mu \text {-bpp })_{3}\right\}_{2} \mathrm{Ni}^{\prime} \mathrm{Ni}^{\prime \prime}{ }_{2}\left(\mu_{3}-\mathrm{OH}\right)\right]\left(\mathrm{ClO}_{4}\right)_{2} \cdot 2.5 \mathrm{CH}_{3} \mathrm{CN}$ $\left(\mathbf{1}^{2+}\right)$ and $\left[\left\{\mathrm{Ni}^{\prime \prime}(\mu-\mathrm{bpp})_{3}\right\}_{2} \mathrm{Ni}_{3}{ }_{3}\left(\mu_{3}-\mathrm{OH}\right)\right]\left(\mathrm{ClO}_{4}\right)_{3} \cdot 1.5 \mathrm{CH}_{3} \mathrm{CN} \cdot\left(\mathrm{CH}_{3} \mathrm{CH}_{2}\right)_{2} \mathrm{O} \quad\left(1^{3+}\right)$, (apical, ap; equatorial, eq).
$1^{2+}$
$1^{3+}$

Average of $\mathrm{Ni}_{a p}-\mathrm{N}$ distances in apical position
$\begin{array}{lll}\mathrm{Ni}(3)_{\mathrm{ap}}-\mathrm{N} & \mathrm{Ni}(4)_{\mathrm{ap}}-\mathrm{N} & 2.10(5) \\ & \mathrm{Ni}(5)_{\mathrm{ap}}-\mathrm{N} & 2.11(5)\end{array}$

Average of $\mathrm{Ni}_{\text {eq }}-\mathrm{N}, \mathrm{O}$ distances in the equatorial position (core)

$\begin{array}{llll}\mathrm{Ni}(1)_{\text {eq }}-\mathrm{N}, \mathrm{O} & 2.00(3) & \mathrm{Ni}(1)_{\text {eq }}-\mathrm{N}, \mathrm{O} & 2.02(3) \\ \mathrm{Ni}(2)_{\text {eq }}-\mathrm{N}, \mathrm{O} & 2.04(3) & \mathrm{Ni}(2)_{\text {eq }}-\mathrm{N}, \mathrm{O} & 2.03(3) \\ & & \mathrm{Ni}(3)_{\text {eq }}-\mathrm{N}, \mathrm{O} & 2.02(2)\end{array}$

$\mathrm{Ni}_{\text {eq }}-\mathrm{O}$ distances

$\begin{array}{llll}\mathrm{Ni}(1)_{\text {eq }}-\mathrm{O} & 2.272(4) & \mathrm{Ni}(1)_{\text {eq }} \mathrm{O} & 2.008(5) \\ \mathrm{Ni}(2)_{\text {eq }}-\mathrm{O} & 1.9437(17) & \mathrm{Ni}(2)_{\text {eq }} \mathrm{O} & 2.031(5)\end{array}$

$\mathrm{Ni}(2)_{\text {eq } \# 1-\mathrm{O}} \quad 1.9438(17) \quad \mathrm{Ni}(3)_{\text {eq }}-\mathrm{O} \quad 2.025(5)$

$\mathrm{Ni}$ eq-O-Nieq angles

$\mathrm{Ni}(2)_{\text {eq }}-\mathrm{O}-\mathrm{Ni}(2)_{\text {eq } \# 1} \quad 135.1(2) \quad \mathrm{Ni}(1)_{\text {eq }}-\mathrm{O}-\mathrm{Ni}(3)_{\text {eq }} \quad 121.2(3)$

$\mathrm{Ni}(2)_{\text {eq }}-\mathrm{O}-\mathrm{Ni}(1)_{\text {eq }} \quad 112.44(12) \quad \mathrm{Ni}(1)_{\text {eq }}-\mathrm{O}-\mathrm{Ni}(2)_{\text {eq }} \quad 120.6(2)$

$\mathrm{Ni}(1)_{\text {eq }}-\mathrm{O}-\mathrm{Ni}(2)_{\text {eq }} \# 1 \quad 112.44(12) \quad \mathrm{Ni}(3)_{\text {eq }}-\mathrm{O}-\mathrm{Ni}(2)_{\text {eq }} \quad 117.7(3)$

$\# 1:-x+1, y,-z+3 / 2$

\begin{tabular}{lllll}
\hline \multicolumn{2}{c}{$1^{2+}$} & & $1^{3+}$ & \\
\hline \multirow{2}{*}{$\mathrm{Ni}_{\text {aq }} \cdots \mathrm{Ni}$ eq } & $\mathrm{Ni}(3) \cdots \mathrm{Ni}(1)$ & $4.3007(3)$ & $\mathrm{Ni}(4) \cdots \mathrm{Ni}(1)$ & $4.3379(2)$ \\
& $\mathrm{Ni}(3) \cdots \mathrm{Ni}(2)$ & $4.4490(4)$ & $\mathrm{Ni}(4) \cdots \mathrm{Ni}(2)$ & $4.33182(14)$ \\
& $\mathrm{Ni}(3) \cdots \mathrm{Ni}(2) \# 1$ & $4.2816(3)$ & $\mathrm{Ni}(4) \cdots \mathrm{Ni}(3)$ & $4.33814(16)$ \\
& & & $\mathrm{Ni}(5) \cdots \mathrm{Ni}(1)$ & $4.29127(13)$ \\
& & & $\mathrm{Ni}(5) \cdots \mathrm{Ni}(2)$ & $4.3209(2)$ \\
& & & $\mathrm{Ni}(5) \cdots \mathrm{Ni}(3)$ & $4.3295(2)$ \\
$\mathrm{Ni}_{\text {eq }} \cdots \mathrm{Ni}_{\text {eq }}$ & $\mathrm{Ni}(1) \cdots \mathrm{Ni}(2)$ & $3.5089(2)$ & $\mathrm{Ni}(1) \cdots \mathrm{Ni}(2)$ & $3.50908(12)$ \\
& $\mathrm{Ni}(1) \cdots \mathrm{Ni}(2) \# 1$ & $3.5089(2)$ & $\mathrm{Ni}(1) \cdots \mathrm{Ni}(3)$ & $3.51358(14)$ \\
& $\mathrm{Ni}(2) \cdots \mathrm{Ni}(2) \# 1$ & $3.5930(3)$ & $\mathrm{Ni}(2) \cdots \mathrm{Ni}(3)$ & $3.47117(14)$ \\
& & & $\mathrm{Ni}(4) \cdots \mathrm{Ni}(5)$ & $7.6485(3)$ \\
\hline \multirow{2}{*}{$\mathrm{Ni}_{\text {aq }} \cdots \mathrm{Ni}_{\text {aq }}$} & $\mathrm{Ni}(3) \cdots \mathrm{Ni}(3) \# 1$ & $7.6681(7)$ & & \\
\hline
\end{tabular}

Table 2. Comparison of selected $\mathrm{Ni} \cdots \mathrm{Ni}$ bond lengths (angstroms) for [ $\left[\mathrm{Ni}^{\prime \prime}(\mu-\right.$ bpp $\left.\left.)_{3}\right\}_{2} \mathrm{Ni}^{\prime} \mathrm{Ni}^{\prime \prime}{ }_{2}\left(\mu_{3}-\mathrm{OH}\right)\right]\left(\mathrm{ClO}_{4}\right)_{2} \cdot 2.5 \mathrm{CH}_{3} \mathrm{CN} \quad\left(\mathbf{1}^{2+}\right)$ and $\left[\left\{\mathrm{Ni}^{\prime \prime}(\mu \text {-bpp })_{3}\right\}_{2} \mathrm{Ni}_{3}\left(\mu_{3}-\right.\right.$ $\mathrm{OH})]\left(\mathrm{ClO}_{4}\right)_{3} \cdot 1.5 \mathrm{CH}_{3} \mathrm{CN} \cdot\left(\mathrm{CH}_{3} \mathrm{CH}_{2}\right)_{2} \mathrm{O}\left(1^{3+}\right)$, (apical, ap; equatorial, eq).

Finally, the intermetallic $\mathrm{Ni} \cdot \cdots \mathrm{Ni}$ distances reveals a slight elongation of the structure in the reduced form, $\mathbf{1}^{2+}$, compared to $1^{3+}$ (Table 1). All these minor structural changes between the $\mathrm{Ni}_{5}$ $\left(1^{3+}\right)$ and $\mathrm{Ni}^{\prime} \mathrm{Ni}_{4}{ }_{4}\left(\mathbf{1}^{2+}\right)$ redox states are similar to those previously observed when comparing the $\mathrm{X}$-ray crystallographic structures of the analogous $\left[\left\{\mathrm{Co}^{\prime \prime}(\mu-\mathrm{bpp})_{3}\right\}_{2} \mathrm{Co}_{3}{ }_{3}\left(\mu_{3}-\mathrm{OH}\right)\right]^{2+}$ and $\left[\left\{\mathrm{Co}^{\prime \prime}(\mu-\right.\right.$ bpp $\left.\left.)_{3}\right\}_{2} \mathrm{Co}^{\prime} \mathrm{Co}_{2}{ }_{2}\left(\mu_{3}-\mathrm{OH}\right)\right]^{2+}$ complexes, in which, the reduction of the $\mathrm{Co}$ (II) ion to $\mathrm{Co}(\mathrm{I})$ takes also place in the core. Few examples of triangular trinuclear nickel complexes featuring a $\mathrm{Nill}_{3}\left(\mu_{3}-\right.$ $\mathrm{OH}),{ }^{[65-68]}$ and a $\mathrm{Ni}_{3}\left(\mu_{3}-\mathrm{O}\right)^{[69-70]}$ core have been reported and only one example of a mixed-valence trinuclear $\mathrm{Ni}_{2}{ }_{2} \mathrm{Ni}^{\prime \prime \prime}\left(\mu_{3}-\mathrm{OH}\right)$ center as unit in a porous framework. ${ }^{[71]}$ The nickel ions in these complexes are either tetra- or hexa-coordinated while unusual five-coordinated metal ions are found in the $\mathrm{Ni}_{3}{ }^{11}\left(\mu_{3}-\mathrm{OH}\right)$ core in $\mathbf{1}^{3+}$ and $\mathbf{1}^{2+}$. In addition, the number of isolated and fully characterized $\mathrm{Ni}(\mathrm{I})$ complexes is still limited. ${ }^{[72-76]}$ [77] To the best of our knowledge, an hydroxo-centered $\left\{\mathrm{Ni}^{\prime} \mathrm{Ni}_{2}{ }^{\prime \prime}\left(\mu_{3}-\mathrm{OH}\right)\right\}^{4+}$ 
trinuclear with one $\mathrm{Ni}$ ion at the $+\mathrm{I}$ oxidation state as the central unit present in $\mathbf{1}^{2+}$ has never been reported and only one mixedvalence trinuclear complex $\mathrm{Ni}^{\prime \prime}-\mathrm{Ni}^{\mathrm{l}}-\mathrm{Ni}^{\prime \prime}$ presenting a linear geometry has been recently published. ${ }^{[78]}$ The stability of the $\left\{\mathrm{Ni}^{\prime} \mathrm{Ni}_{2}{ }^{11}\left(\mu_{3}-\mathrm{OH}\right)\right\}^{4+}$ trinuclear core in $\mathbf{1}^{2+}$ can be correlated with this particular pentanuclear structure, the presence of the two apical sites maintaining the trinuclear core through the six bridging bppligands.

\subsection{Electrochemical properties of $1^{3+}$ in $\mathrm{CH}_{3} \mathrm{CN}$ and characterizations by UV-Vis and EPR spectroscopy in different redox states: $1^{2+}, 1^{3+}, 1^{4+}$ and $1^{5+}$}

The electrochemical properties of $\mathbf{1}^{3+}$ was studied in $\mathrm{CH}_{3} \mathrm{CN}$, $\left[\mathrm{Bu}_{4} \mathrm{~N}\right] \mathrm{ClO}_{4}$ under an argon atmosphere. Table 3 summarizes the redox potentials of this complex, as well as those of the analogous $\mathrm{Mn}, \mathrm{Fe}$ and Co for comparison. The cyclic voltammogram of $\mathbf{1}^{3+}$ reveals two successive reversible oxidation waves at $E_{1 / 2}=+1.11$ and $+1.37 v s \mathrm{Ag} / \mathrm{AgNO}_{3}(\triangle E \mathrm{p}=60 \mathrm{mV}$ for each of them), followed by a third quasi-reversible one at $E_{1 / 2}=+1.72 \mathrm{~V}$ (Figures 2, 3 and $\mathrm{S1}$ ), consistent with the successive one-electron oxidation of three of the $\mathrm{Ni}(\mathrm{II})$ ions of the pentanuclear into $\mathrm{Ni}$ (III) (redox processes: $\mathrm{Ni}_{5} / \mathrm{Ni}_{4}{ }_{4} \mathrm{Ni}^{11 \prime}\left(\mathbf{1}^{3+/ 4+}\right), \quad \mathrm{Ni}_{4}{ }_{4} \mathrm{Ni}^{\prime \prime \prime} / \mathrm{Ni}{ }_{3} \mathrm{Ni}^{\prime \prime \prime}{ }_{2} \quad\left(\mathbf{1}^{4+/ 5+}\right)$ and $\left.\mathrm{Ni}_{3}{ }_{3} \mathrm{Ni}_{2}{ }_{2} / \mathrm{Ni}_{2} \mathrm{Ni}^{\mathrm{III}}{ }_{3}\left(1^{5+/ 6+}\right)\right)$. Two reversible one-electron reduction waves are also observed at $E_{1 / 2}=-1.59$ and $-2.01 \mathrm{~V}$ assigned to the successive reduction of two $\mathrm{Ni}$ (II) ions of the complex into "Ni(I)" (redox processes: $\mathrm{Ni}_{5} / \mathrm{Ni}^{\prime} \mathrm{Ni}_{4},\left(\mathbf{1}^{3+/ 2+}\right)$ and $\mathrm{Ni}^{\prime} \mathrm{Ni}_{4} / \mathrm{Ni}_{2}{ }_{2} \mathrm{Ni}_{3}$ $\left(1^{2+/+}\right)$, respectively). It should be noted that the reduction can be either metal or ligand-centered. However, since $\left[\left\{Z \mathrm{n}^{\prime \prime}(\mu-\right.\right.$ bpp $\left.\left.)_{3}\right\}_{2} \mathrm{Zn}_{3}{ }_{3}\left(\mu_{3}-\mathrm{OH}\right)\right]^{3+}$ containing redox inactive $\mathrm{Zn}^{2+}$ ions does not show any redox process in the potential region from +1.2 to -2.3 $\checkmark v s \mathrm{Fc} / \mathrm{Fc}^{+}{ }^{\left[{ }^{[53]}\right.}$ the reductive reversible processes observed for $1^{3+}$ as well as those of the Co analogue are most probably metalbased. ${ }^{[53-55]}$ For $\mathbf{1}^{3+}$, additional reduction waves located at more negative potential can be detected when the cyclic voltammogram is recorded on a carbon vitreous electrode: an irreversible wave at $E \mathrm{p}_{\mathrm{c}}=-2.36 \mathrm{~V}$ followed by two quasi-reversible waves at 2.52 and $-2.65 \mathrm{~V}$ (Figure 3 ). The irreversibility of the process at -2.36 $\checkmark$ points out a chemical reaction coupled to the electron transfer and thus the instability of the three-electron reduced neutral species, $\mathbf{1}^{0}$. On the basis of the X-ray structure analysis of the one-electron reduced complex, $\mathbf{1}^{2+}$, isolated after a bulk electrolysis at $-1.70 \mathrm{~V}$ (see below), it is possible to localize the site of the first reduction process $\left(E_{1 / 2}=-1.59 \mathrm{~V}\left(1^{3+/ 2+}\right)\right)$ to the reduction of one $\mathrm{Ni}(\mathrm{II})$ into $\mathrm{Ni}(\mathrm{I})$ in the central core. The further reduction process at $E_{1 / 2}=-2.01 \mathrm{~V}\left(1^{2+/+}\right)$, likewise reversible, can be thus reasonably attributed to the reduction of another $\mathrm{Ni}(\mathrm{II})$ ion of the central core while the third one at $E \mathrm{p}_{\mathrm{c}}=-2.36 \mathrm{~V}$, irreversible, to the reduction of the last $\mathrm{Ni}(\mathrm{II})$ of the central core leading to the degradation of the complex. Based on this analysis, the two first oxidation process can be assigned to the successive one-electron oxidation of the two apical $\mathrm{Ni}(\mathrm{II})$ ions whereas the third one to the oxidation of one $\mathrm{Ni}$ (II) of the central core.

Given that four well-separated reversible one-electron waves are observed by cyclic voltammetry revealing the potential stability of the complex in the following four redox states, $\mathrm{Ni}_{4}{ }_{4} \mathrm{Ni}^{\mathrm{III}}\left(1^{4+}\right)$, $\mathrm{Ni}_{3}{ }_{3} \mathrm{Ni}{ }_{2}{ }_{2}\left(\mathbf{1}^{5+}\right), \mathrm{Ni}^{\prime} \mathrm{Ni}_{4}{ }_{4}\left(\mathbf{1}^{2+}\right), \mathrm{Ni}_{2} \mathrm{Ni}_{3}\left(\mathbf{1}^{+}\right)$, exhaustive electrolyses have been carried out in order to evaluate their stability in bulk. $1^{4+}, 1^{5+}$ and $1^{2+}$ were quantitatively generated by exhaustive electrolyses of a solution of $1^{3+}$ at $+1.20,+1.50$ and $-1.70 \mathrm{~V}$, respectively (about one-electron exchanged in each case (with $\mathbf{1}^{5+}$ electrogenerated from $\mathbf{1}^{4+}$, Figure 2)). Electrogenerated solutions are perfectly stable as illustrated by the resulting cyclic voltammograms (Figures 2(B-D)), confirming the high stability of the triple-helicate pentanuclear structure in four different redox states, $\mathbf{1}^{2+}, \mathbf{1}^{3+}, \mathbf{1}^{4+}$ and $\mathbf{1}^{5+}$. By contrast, the two-electron-reduced species $1^{+}$is not perfectly stable since the solution obtained at the end of the electrolysis at $-2.05 \mathrm{~V}$ has undergone some degradation as shown by the resulting cyclic voltammogram which exhibits poorly defined additional waves (Figure 2(E)).

Dark grey single crystals of $1\left(\mathrm{ClO}_{4}\right)_{2} \cdot 2.5 \mathrm{CH}_{3} \mathrm{CN}$ were easily obtained by slow vapor diffusion of diethylether into the electrogenerated solution of $1^{2+}$. On the other hand, attempts to obtain crystals of the oxidized species $1^{4+}$ and $1^{5+}$ by the same procedure systematically led to the formation of single crystals corresponding to the initial species $\mathbf{1}^{3+}$.

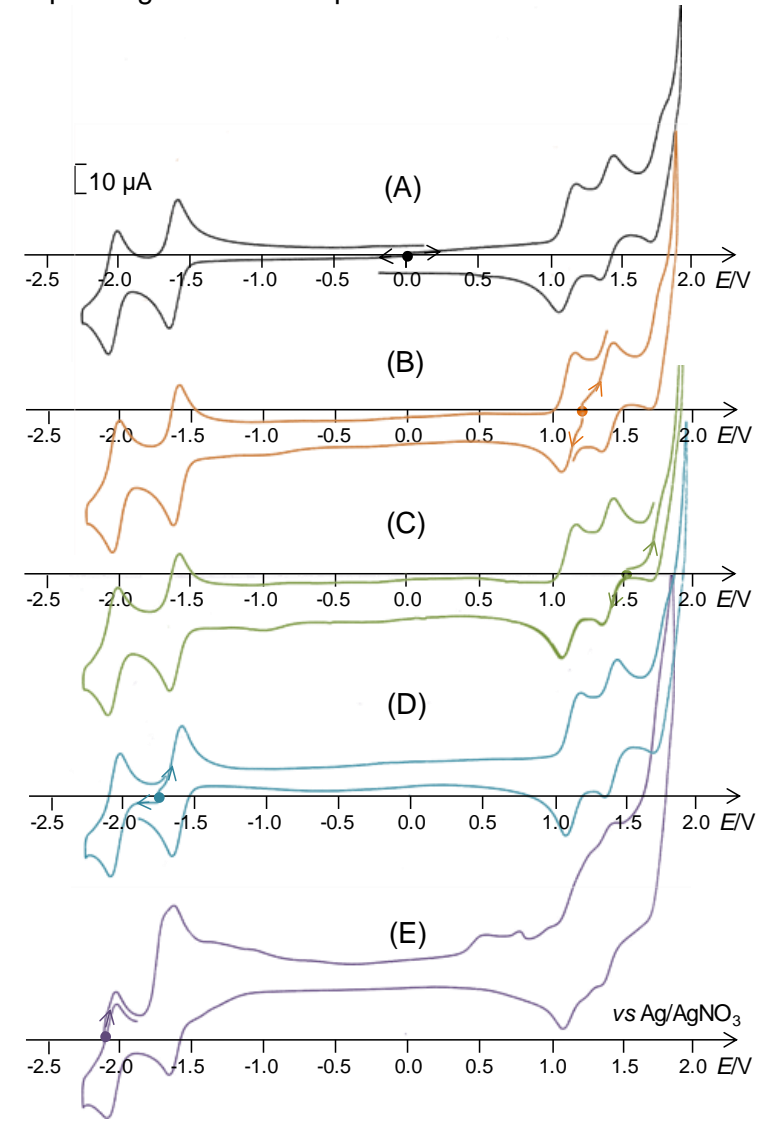

Figure 2. Cyclic voltammograms in $\mathrm{CH}_{3} \mathrm{CN}, 0.05 \mathrm{M}\left[\mathrm{Bu}_{4} \mathrm{~N}\right] \mathrm{ClO}_{4}$ at a platinum electrode (diameter $5 \mathrm{~mm}$ ) of $(A)$ a $0.5 \mathrm{mM}$ solution of $1^{3+}$, (B) after exhaustive oxidation at $+1.20 \mathrm{~V}$ of the (A) solution (formation of $1^{4+}$ ), (C) after exhaustive oxidation at $+1.50 \mathrm{~V}$ of the (B) solution (formation of $1^{5+}$ ), (D) after exhaustive reduction at $-1.70 \mathrm{~V}$ of the $(\mathrm{A})$ solution (formation of $1^{2+}$ ), (E) after exhaustive reduction at $-2.05 \mathrm{~V}$ of the $(\mathrm{D})$ solution (partial formation of $\mathbf{1}^{+}$). Scan rate of 100 $m V . s^{-1}$.

This can be easily explained by the fact that these species oxidizing at a high potential $\left(E_{1 / 2}=+1.11\right.$ and $\left.+1.37 \mathrm{~V}\right)$ are easily reduced by residual water present in the solvents. In the case of the cobalt derivative, the doubly oxidized species $\left[\left\{\mathrm{Co}^{\prime \prime \prime}(\mu-\right.\right.$ bpp $\left.\left.)_{3}\right\}_{2} \mathrm{Co}_{3}{ }_{3}\left(\mu_{3}-\mathrm{OH}\right)\right]^{5+}$ much more stable $\left(E_{1 / 2}=-0.21\right.$ $\left(\mathrm{Co}_{5} / \mathrm{Co}_{4}{ }_{4} \mathrm{Co}{ }^{\prime \prime \prime}\right)$ and $+0.11 \mathrm{~V}\left(\mathrm{Co}_{4}{ }_{4} \mathrm{Co}^{\prime \prime \prime} / \mathrm{Co}_{3}{ }_{3} \mathrm{Co}^{\prime \prime \prime}{ }_{2}\right)$, Table 3$)$ was easily crystallized and characterized by $\mathrm{X}$-ray diffraction, showing unambiguously that the two successive oxidation processes for 
this complex (high-spin Co(II) ions into low-spin Co(III) ions) take place in the apical positions. ${ }^{[54]}$

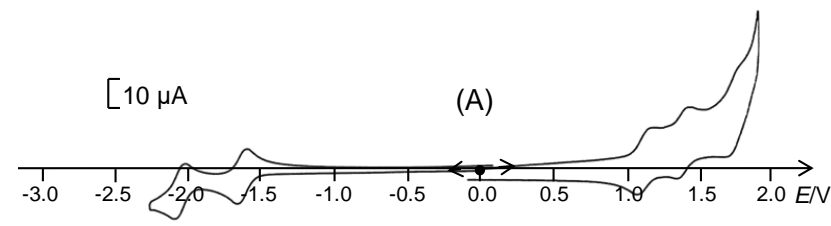

(B)

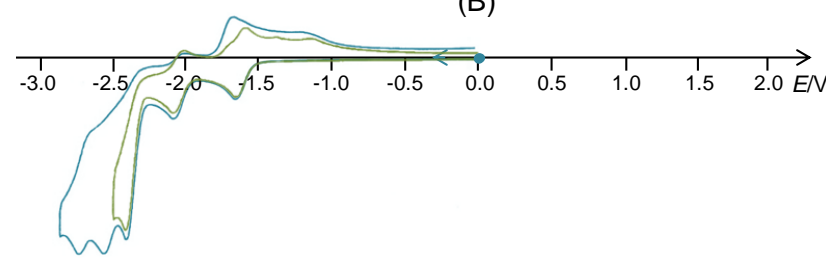

Figure 3. Cyclic voltammograms in $\mathrm{CH}_{3} \mathrm{CN}, 0.05 \mathrm{M}\left[\mathrm{Bu}_{4} \mathrm{~N}\right] \mathrm{ClO}_{4}$ at a carbon electrode (diameter $3 \mathrm{~mm}$ ) of a $0.5 \mathrm{mM}$ solution of $1^{3+}$, (A) scan range 0 to 1.9 $\mathrm{V}$ and 0 to $-2.2 \mathrm{~V},(\mathrm{~B})$ scan range 0 to $-2.8 \mathrm{~V}$. Scan rate of $100 \mathrm{mV}^{-1}$.

Initial and electrogenerated solutions were studied by UV-vis. and EPR spectroscopy (Figure 4). The initial pale green solution of $\mathbf{1}^{3+}$ turns to green after a oxidation to $1^{4+}$, and to a more intense green after formation of $\mathbf{1}^{5+}$ with the appearance of a large visible absorption bands from $550 \mathrm{~nm}$ to $800 \mathrm{~nm}\left(\lambda_{\max }\right.$ of $\left.700 \mathrm{~nm}\right)$ associated with a shoulder at about $400 \mathrm{~nm}$ (Figure 4(A-a,c)), in accordance with the oxidation of $\mathrm{Ni}(\mathrm{II})$ into $\mathrm{Ni}(\mathrm{III}) .{ }^{[72]}$ Upon reduction of $1^{3+}$ to $1^{2+}$, the solution turns to black purple with an increase of the absorption in the $400-800 \mathrm{~nm}$ region and the appearance of two broad bands at about 500 and $725 \mathrm{~nm}$, in agreement with the generation of a $\mathrm{Ni}(\mathrm{I})$ species (Figure 4(A-d)). ${ }^{72}$ 78] The intensity of these bands further increases upon reduction of $\mathbf{1}^{2+}$ to $\mathbf{1}^{+}$, in agreement with the reduction of a second $\mathrm{Ni}(\mathrm{II})$ ion in $\mathrm{Ni}(\mathrm{I})$ of the central core. However, as discussed above, $\mathbf{1}^{+}$, is not perfectly stable and the resulting UV-vis. spectrum may include some contributions of decomposition products. It should be noted that the electrolyzed solutions of $\mathbf{1}^{2+}$ and $\mathbf{1}^{+}$remain homogeneous. The strong increase of the absorption of the solutions in the whole visible spectrum is thus only the result of the dark black color of the solutions.

The X-band spectra of the initial and electrogenerated solutions have been recorded at $100 \mathrm{~K}$ (Figure $4(\mathrm{~B})$ ). The initial trication $\mathbf{1}^{3+}$ proved to be difficult to detect by X-band EPR at $100 \mathrm{~K}$. We assigned this behaviour to the large zero field splitting parameter $|D|$ expected for high spin $\mathrm{Ni}(\mathrm{II})$ ions, ${ }^{[79]}$ especially in magnetically exchange-coupled polynuclear complexes. ${ }^{[80]}$ Both the oneelectron oxidized $\mathbf{1}^{4+}$ and two-electron oxidized $\mathbf{1}^{5+}$ also proved to be hard to detect, presumably for the same reasons (Figure $4(B, b, c))$. The spectrum of the one-electron reduced species $1^{2+}$ displays a broad unresolved feature of low intensity at $\mathrm{g}_{\text {iso }} \sim 2.1$ (Figure $4(B-d)$ ). The measured $g_{\text {iso }}$ value is comparable to that reported for magnetically coupled $\mathrm{Ni}_{2}{ }_{2} \mathrm{Ni}^{1}$ trimers, ${ }^{[78]}$ while no power saturation was observed even at $200 \mathrm{~mW}$, as expected for coupled polynuclear systems (Figure S2). The EPR spectrum of the two-electron reduced $\mathbf{1}^{+}$shows a typical axial "Ni(I)" signature at $g_{/ /}=2.239$ and $g_{-} \_=2.061$, superimposed to a sharp $(S=1 / 2)$ radical line at $g=2.000$ (Figure $4(B, e)$ ). These features suggest decomposition of the monocation since injection of a second electron within the nickel core would result in a magnetically coupled integer spin system (hard to detect by EPR). This hypothesis is corroborated by the fact that an alteration of the spectrum was observed upon heating to $200 \mathrm{~K}$ and freezing back to $100 \mathrm{~K}$ (Figure S3). Furthermore, the two signals, namely the " $\mathrm{Ni}^{\text {l" }}$ and radical lines belong to chemically distinct species, as demonstrated by the distinct $\mathrm{P}^{1 / 2}$ values (Figure S3).

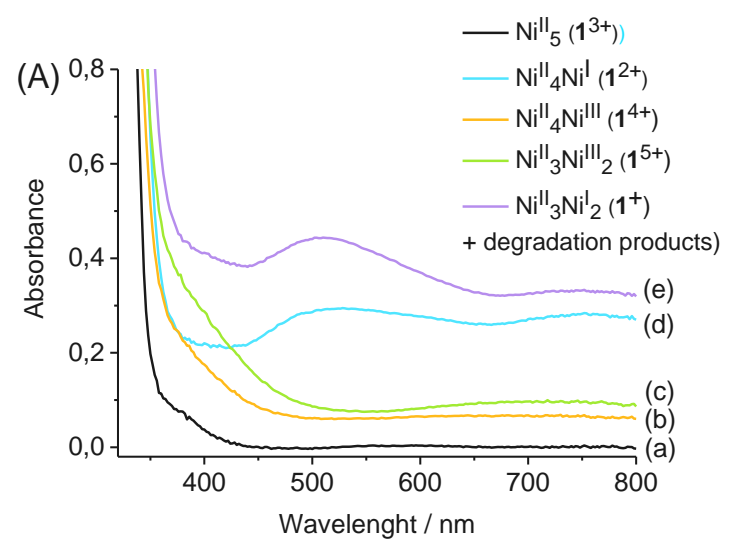

(B)

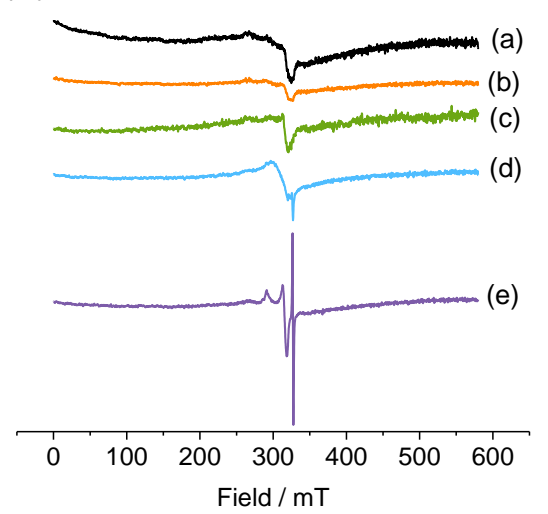

Figure 4. (A) Visible absorption $(I=1 \mathrm{~mm})$ and $(B) X$-Band EPR spectra of a $0.5 \mathrm{mM}$ solution of $\mathbf{1}^{3+}$ in $\mathrm{CH}_{3} \mathrm{CN}, 0.05 \mathrm{M}\left[\mathrm{Bu}_{4} \mathrm{~N}\right] \mathrm{ClO}_{4}$ and (a) after exhaustive oxidation at $+1.20 \mathrm{~V}$ of $\mathbf{1}^{3+}$ (formation of $\mathbf{1}^{4+}$ ), (b) at $+1.50 \mathrm{~V}$ of $\mathbf{1}^{4+}$ (formation of $1^{5+}$ ), (c) after exhaustive reduction at $-1.70 \mathrm{~V}$ of $\mathbf{1}^{3+}$ (formation of $\mathbf{1}^{2+}$ ), (d) after exhaustive reduction at $-2.05 \mathrm{~V}$ of $\mathbf{1}^{2+}$ (partial formation of $\mathbf{1}^{+}$). EPR conditions: microwave freq. $9.42 \mathrm{GHz}$, power: $28 \mathrm{~mW}$, mod. amp. $0.4 \mathrm{mT}$, freq. $100 \mathrm{kHz}, T$ $=100 \mathrm{~K}$.

\subsection{Comparison of the electrochemical behavior of the $\mathrm{Ni}$ pentanuclear complex with the analogous $\mathrm{Mn}$, Fe and Co}

The multireversible redox behavior identified for the $\mathrm{Ni}$ pentanuclear was previously observed for the $\left[\left\{\mathrm{M}^{\prime \prime}(\mu-\right.\right.$ bpp $\left.\left.)_{3}\right\}_{2} \mathrm{M}_{2}{ }_{2} \mathrm{M}^{\prime \prime \prime}\left(\mu_{3}-\mathrm{O}\right)\right]^{3+}(\mathrm{M}=\mathrm{Mn}$ or $\mathrm{Fe})$ and $\left[\left\{\mathrm{Co} \text { " }(\mu \text {-bpp })_{3}\right\}_{2} \mathrm{Co}_{3}{ }_{3}\left(\mu_{3^{-}}\right.\right.$ $\mathrm{OH})]^{3+}$ derivatives. ${ }^{[52-54,56,61]}$ Such behavior was also evidenced for some families of electronically coupled self-assembled multinuclear complexes presenting helical, ${ }^{[81]}$ grid, ${ }^{[82-85]}$ metallamacrocycle ${ }^{[86]}$ or other type structures. ${ }^{[47,87-88]}$ The cyclic voltammograms of the $\mathrm{Mn}, \mathrm{Fe}, \mathrm{Co}$ and $\mathrm{Ni}$ complexes are reported Figure 5. All pentanuclear complexes display distinct redox behaviors. Since we performed the chemical synthesis under 
aerobic conditions, the $\mathrm{Mn}$ and Fe derivatives, easier to oxidize than the $\mathrm{Co}$ and Ni derivatives $\left(\mathrm{M}^{\prime \prime \prime} \mathrm{M}_{4}{ }_{4} / \mathrm{M}^{\prime \prime}{ }_{5}\right.$ couple: $E_{1 / 2}=-0.58 \mathrm{~V}$ $(\mathrm{Mn})$ and $-0.46 \mathrm{~V}(\mathrm{Fe})$ vs $-0.21 \mathrm{~V}(\mathrm{Co})$ and $+1.11(\mathrm{Ni}))$, were isolated in their mixed-valence $\mathrm{M}^{\prime \prime \prime} \mathrm{M}^{\prime \prime}{ }_{4}$ forms (Table 3). The $\mathrm{Mn}$ and $\mathrm{Fe}$ complexes featuring a trinuclear oxo-centered core, demonstrated five reversible metal-centered $\mathrm{M}^{\prime \prime \prime} / \mathrm{M}^{\prime \prime}$ waves, all being located between -0.58 and $+1.33 \mathrm{~V}$ vs $\mathrm{Ag} / \mathrm{AgNO}_{3}$ (Figure $5(\mathrm{~A}, \mathrm{~B})$ and Table 3). ${ }^{[52,61]}$

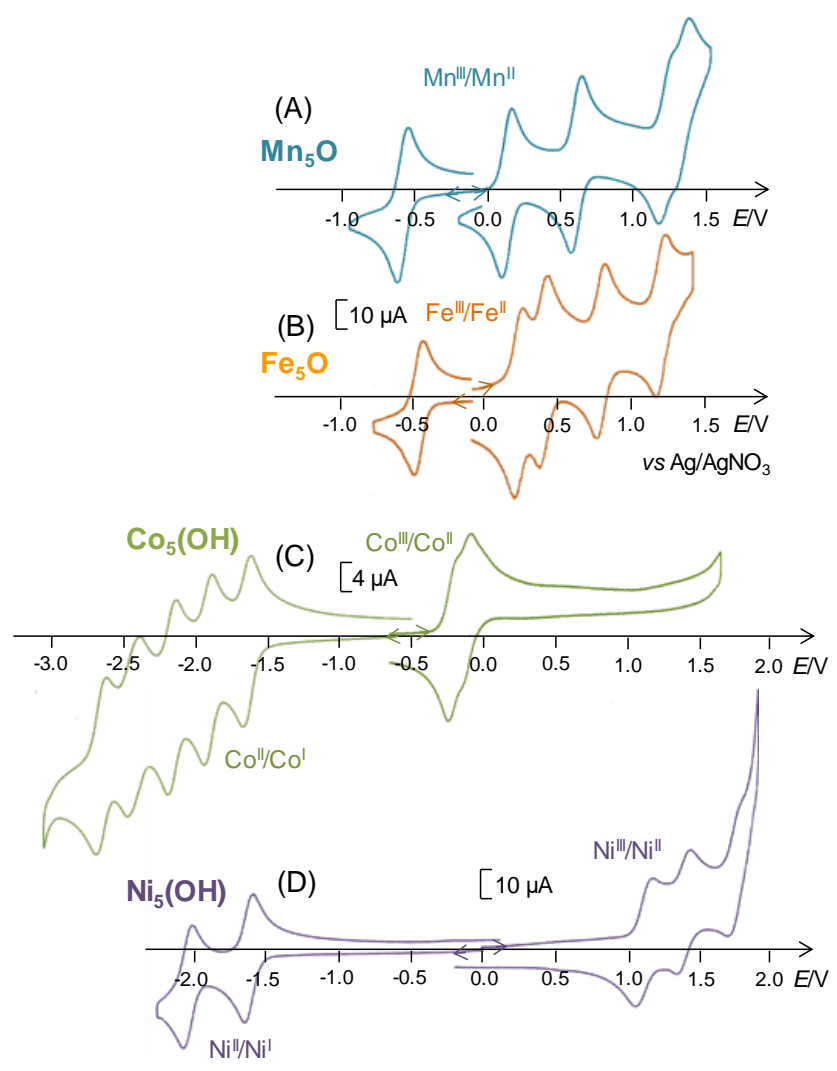

Figure 5. Cyclic voltammograms in $\mathrm{CH}_{3} \mathrm{CN}, 0.05 \mathrm{M}\left[\mathrm{Bu}_{4} \mathrm{~N}\right] \mathrm{ClO}_{4}$ of $(\mathrm{A})$ a $0.7 \mathrm{mM}$ solution of $\left[\left\{\mathrm{Mn}^{\prime \prime}(\mu \text {-bpp })_{3}\right\}_{2} \mathrm{Mn}_{2}{ }_{2} \mathrm{Mn}^{\prime \prime \prime}\left(\mu_{3}-\mathrm{O}\right)\right]^{3+}$ at a Pt electrode (diameter $5 \mathrm{~mm}$ ), (B) a $0.5 \mathrm{mM}$ of $\left[\left\{\mathrm{Fe}^{\prime \prime}(\mu \text {-bpp })_{3}\right\}_{2} \mathrm{Fe}{ }_{2} \mathrm{Fe}^{\prime \prime \prime}\left(\mu_{3}-\mathrm{O}\right)\right]^{3+}$ at a Pt electrode (diameter 5 $\mathrm{mm}),(\mathrm{C})$ a $0.54 \mathrm{mM}\left[\left\{\mathrm{Co}^{\prime \prime}(\mu-\mathrm{bpp})_{3}\right\}_{2} \mathrm{Co}_{3}{ }_{3}\left(\mu_{3}-\mathrm{OH}\right)\right]^{3+}$ at a Pt electrode (scan range -0.82 and $+1.6 \mathrm{~V}$ ) and $\mathrm{C}$ electrode (scan range between -0.5 and $-3.0 \mathrm{~V}$ ) (diameter $3 \mathrm{~mm}$ ) and (D) a $0.5 \mathrm{mM}\left[\left\{\mathrm{Ni}^{\prime \prime}(\mu \text {-bpp })_{3}\right\}_{2} \mathrm{Ni}_{3}\left(\mu_{3}-\mathrm{OH}\right)\right]^{3+}\left(\mathbf{1}^{3+}\right)$ at a $\mathrm{Pt}$ electrode (diameter $5 \mathrm{~mm}$ ). Scan rate of $100 \mathrm{mV} . \mathrm{s}^{-1}$.

More specifically, the first three one-electron transfers in the Mn compound, well-separated, concern the $\mathrm{Mn}$ ions within the central trinuclear $\mathrm{Mn}_{3}\left(\mu_{3}-\mathrm{O}\right)$ core, while the last two oxidation processes, close in potential, to the oxidation of the two apical $\mathrm{Mn}$ (II) ions. For the Fe complex all oxidations occur in the central trinuclear core since upon oxidation of the third central Fe(II) ion, the $\left[\left\{\mathrm{Fe}^{\mathrm{II}}(\mu \text {-bpp })_{3}\right\}_{2} \mathrm{Fe}^{\mathrm{III}}{ }_{3}\left(\mu_{3}-\mathrm{O}\right)\right]^{5+}$ species formed undergoes a striking intramolecular electron transfer, with both metal ions in apical position being simultaneous oxidized while the core is reduced leading to $\left[\left\{\mathrm{Fe}^{\mathrm{III}}(\mu \text {-bpp })_{3}\right\}_{2} \mathrm{Fe}_{2} \mathrm{Fe}^{\mathrm{III}}\left(\mu_{3}-\mathrm{O}\right)\right]^{5+}$. The $\mathrm{Mn}_{5}, \mathrm{Mn}_{3} \mathrm{Mn}^{\prime \prime \prime}{ }_{2}$ and $\mathrm{Mn}_{2} \mathrm{Mn}^{\prime \prime \prime}{ }_{3}$ as well as the $\mathrm{Fe}_{5}{ }_{5}, \mathrm{Fe}_{3}{ }_{3} \mathrm{Fe}^{\prime \prime \prime}, \mathrm{Fe}_{2}{ }_{2} \mathrm{Fe}^{\prime \prime \prime}{ }_{3}$ and $\mathrm{Fe}^{\mathrm{II}} \mathrm{Fe}^{\mathrm{III}}{ }_{4}$ were quantitatively generated by bulk electrolyses demonstrating the high stability of the pentanuclear complexes in four redox states (from $\mathrm{Mn}_{5}$ to $\mathrm{Mn}_{2}{ }_{2} \mathrm{Mn}_{3} \mathrm{II}_{3}$ ) for the $\mathrm{Mn}$ and up to five oxidation states (from $\mathrm{Fe}_{5}{ }_{5}$ to $\mathrm{Fe}^{\prime \prime} \mathrm{Fe}{ }^{\prime \prime \prime}$ ) for the Fe derivative (Table 4). Their characterization by UV-visible spectroscopy and for some redox states by EPR, magnetism, Mössbauer and by $X-$ ray diffraction for $\left[\left\{\mathrm{Mn}^{\prime \prime}(\mu \text {-bpp })_{3}\right\}_{2} \mathrm{Mn}^{\prime \prime} \mathrm{Mn}^{\prime \prime \prime}{ }_{2}\left(\mu_{3}-\mathrm{O}\right)\right]^{4+}$ allowed to clearly locate the sites of the successive oxidations (Table 4).

Pentanuclear complexes featuring a trinuclear hydroxo-centered core have been isolated with $\mathrm{Cu}, \mathrm{Ni}, \mathrm{Co}$ and $\mathrm{Zn}$ (Table 4). To the best of our knowledge, the electrochemical properties of the $\mathrm{Cu}$ complex are still unexplored. The three redox states $+\mathrm{I},+\mathrm{Il}$ and $+\mathrm{III}$ are accessible for $\mathrm{Ni}$ and $\mathrm{Co}$. The Co complex exhibits five reversible reduction waves between -1.5 and -2.7 V. Five reduction processes are also observed for the $\mathrm{Ni}$ derivative in a similar potential range, but only the two first processes appear reversible. These observations reflect a better stability of the Co compound, in particular in the reduced states, compared to the $\mathrm{Ni}$ derivative. The $\mathrm{Zn}$ complex in $\mathrm{CH}_{3} \mathrm{CN}$ does present any redox activity in the solvent electroactivity domain, ${ }^{[55]}$ suggesting metalbased reduction processes rather than ligand-centered for both derivatives. In addition, the X-ray structural characterization of the electrogenerated mixed-valence $\left[\left\{\mathrm{M}^{\prime \prime}(\mu \text {-bpp })_{3}\right\}_{2} \mathrm{M}^{\prime} \mathrm{M}^{\prime \prime}{ }_{2}\left(\mu_{3}-\mathrm{OH}\right)\right]^{2+}$ $(\mathrm{M}=\mathrm{Co}$ or $\mathrm{Ni}$ ) species strongly suggests that the first reduction process $M(I I)$ into $M(I)$ for both complexes occurs in the central core. Regarding the oxidation processes, only two reversible waves have been observed for the Co derivative, very close in potential, assigned to the successive oxidation of the apical Co(II) ions into $\mathrm{Co}$ (III). None of the oxidation processes of the $\mathrm{Co}$ (II) ions located in the central core can be accessed in the solvent electroactivity domain. The $\mathrm{Ni}$, complex exhibits three wellseparated successive reversible waves that can also be raisonably attributed to the oxidation of the $\mathrm{Ni}(\mathrm{II})$ into $\mathrm{Ni}(\mathrm{III})$ starting by the two apical $\mathrm{Ni}(\mathrm{II})$, even if we have no experimental confirmation, like in the case of Co for which, as state above, the two-oxidized [\{Coll' $\left.\left.(\mu \text {-bpp })_{3}\right\}_{2} \mathrm{Co}_{3}{ }_{3}\left(\mu_{3}-\mathrm{OH}\right)\right]^{5+}$ form was structurally characterized (Table 4). However, we can notice that $\mathrm{Ni}$ ions in the pentanuclear structure are much more difficult to oxidize than the equivalent $C_{0}$ ions, the first oxidation process being located at $E_{1 / 2}=+1.11\left(\mathrm{Ni}_{5} / \mathrm{Ni}^{\prime \prime}{ }_{4} \mathrm{Ni}{ }^{\prime \prime \prime}\right)$ and $-0.21 \mathrm{~V}\left(\mathrm{Co}_{5}{ }_{5} / \mathrm{Co}_{4}{ }_{4} \mathrm{Co}^{\prime \prime \prime}\right)$, respectively. Several mixed-valence states were also quantitatively generated by bulk electrolyses and spectroscopically characterized: $\mathrm{Co}^{\prime} \mathrm{Co}_{4}{ }_{4}$ and $\mathrm{Co}_{3}{ }_{3} \mathrm{Co}^{\prime \prime \prime}{ }_{2}$ and as shown above, $\mathrm{Ni}^{\prime} \mathrm{Ni}_{4}{ }_{4}, \mathrm{Ni}_{4}{ }_{4} \mathrm{Ni}^{\prime \prime \prime}$ and $\mathrm{Ni}_{3}{ }_{3} \mathrm{Ni}^{\prime \prime \prime}{ }_{2}$ (Table 4). 
Table 3. Electrochemical properties of the bis(triple-helicate) pentanuclear complexes $\left[\left\{\mathrm{M}^{\prime \prime}(\mu \text {-bpp })_{3}\right\}_{2} \mathrm{M}_{2}^{\prime \prime} \mathrm{M}^{\prime \prime \prime}\left(\mu_{3}-\mathrm{O}\right)\right]^{3+}(\mathrm{M}=\mathrm{Fe}$ and $\mathrm{Mn})$ and $\left.\left[\mathrm{M}^{\prime \prime}(\mu \text {-bpp })_{3}\right\}_{2} \mathrm{M}^{\prime \prime}{ }_{3}\left(\mu_{3}-\mathrm{OH}\right)\right]^{3-}$ $(\mathrm{M}=\mathrm{Co}$ and $\mathrm{Ni})$ in $\mathrm{CH}_{3} \mathrm{CN}$. With this $\mathrm{Ag} / 0.01 \mathrm{M} \mathrm{AgNO}_{3}$ reference electrode, the ferrocene/ferrocenium $\left(\mathrm{Fc} / \mathrm{Fc} \mathrm{c}^{+}\right.$reversible wave is located at $E_{1 / 2}=100 \mathrm{mV}$. Potentials

\begin{tabular}{|c|c|c|c|}
\hline & \multicolumn{2}{|l|}{$E_{1 / 2}(\mathrm{~V})$ vs. $\mathrm{Ag} / 0.01 \mathrm{M} \mathrm{AgNO}_{3}$} & \multirow[t]{2}{*}{ Ref } \\
\hline Complex & $\mathrm{M}^{11 / 1}$ & $M^{111 / 11}$ & \\
\hline$\left[\left\{\mathrm{Ni}^{\prime \prime}(\mu-\mathrm{bpp})_{3}\right\}_{2} \mathrm{Ni}_{3}{ }_{3}\left(\mu_{3}-\mathrm{OH}\right)\right]^{3+}$ & $-2.65^{\text {qrev }},-2.52^{\text {irrev }},-2.36^{\text {irrev }},{ }^{[a]}-2.01,^{[\mathrm{a}]}-1.59^{[a]}$ & $+1.11,^{[\mathrm{b}]}+1.37,^{[\mathrm{b}]}+1.72^{\mathrm{qrev}[\mathrm{a}]}$ & This work \\
\hline \multirow[t]{2}{*}[\{\mathrm{Co}^{\prime\prime}(\mu-\mathrm{bpp})_{3}\}_{2}\mathrm{Co}_{3}{}_{3}(\mu_{3}-\mathrm{OH})]{$^{3+}$} & $-2.60,,^{[b]}-2.40,{ }^{[b]}-2.14,^{[a]}-1.88,,^{[a]}-1.63^{[a]}$ & $-0.21,[b]+0.11^{[b]}$ & {$[54]$} \\
\hline & \multicolumn{2}{|l|}{$M^{111 / I I}$} & \\
\hline$\left[\left\{\mathrm{Fe}^{\prime \prime}(\mu-\mathrm{bpp})_{3}\right\}_{2} \mathrm{Fe}_{2}{ }_{2} \mathrm{Fe}^{\prime \prime \prime}\left(\mu_{3}-\mathrm{O}\right)\right]^{3+}$ & \multicolumn{2}{|l|}{$-0.46,,^{[a]}+0.21,{ }^{[a]}+0.39,[c]+0.79,,^{[a]}+1.19^{[a]}$} & {$[61]$} \\
\hline$\left[\left\{\mathrm{Mn}^{\prime \prime}(\mu-\mathrm{bpp})_{3}\right\}_{2} \mathrm{Mn}_{2}{ }_{2} \mathrm{Mn}^{\prime \prime \prime}\left(\mu_{3}-\mathrm{O}\right)\right]^{3+}$ & \multicolumn{2}{|l|}{$-0.58,{ }^{[\mathrm{a}]}+0.13,^{[\mathrm{a}]}+0.61,^{[\mathrm{a}]} 1.21,^{[\mathrm{b}]}+1.33^{[\mathrm{b}]}$} & [52] \\
\hline$\left[\left\{\mathrm{Zn}^{\|}(\mu-\mathrm{bpp})_{3}\right\}_{2} \mathrm{Zn}_{3}{ }_{3}\left(\mu_{3}-\mathrm{OH}\right)\right]^{3+}$ & \multicolumn{2}{|c|}{ No redox systems in the potential range 1.2 to $-2.3 \mathrm{~V}[\mathrm{c}]$} & {$[51,53]$} \\
\hline
\end{tabular}

referred versus $\mathrm{Ag} / 0.01 \mathrm{M} \mathrm{AgNO}_{3}$ can be converted versus SCE by adding $298 \mathrm{mV}$.

[a] $\mathrm{M}$ in equatorial position. [b] $\mathrm{M}$ in axial position. [c] For this redox process, the oxidation occurring in the $\mu_{3}-\mathrm{O}$ central core induces a striking electronic intramolecular rearrangement, both metals in axial position being oxidized while the core is reduced to the $\left[\mathrm{Fe}^{\mathrm{III}} \mathrm{Fe}^{\mathrm{II}}\left(\mu_{3}-\mathrm{O}\right)\right]^{5+}$ oxidation level. For the irreversible peak the cathodic peak potential $\left(E_{\mathrm{c}}\right)$ is given, and for the quasi-reversible $\left(\mathrm{q}_{\mathrm{rev}}\right)$, the $E_{1 / 2}$ is given. [c] Potentials are given vs $\mathrm{Fc} / \mathrm{Fc}^{+}$.

Table 4. Bis(triple-helicate) pentanuclear complexes isolated by a chemical synthesis and their associated stable oxidized and reduced states obtained by quantitative electrolyses and characterization methods.

\begin{tabular}{|c|c|c|}
\hline Complex & Synthesis and characterizations methods & Ref \\
\hline $\mathbf{M n}_{5}:\left[\left\{\mathrm{Mn}^{\|}(\mu-\mathrm{bpp})_{3}\right\}_{2} \mathrm{Mn}_{3}{ }_{3}\left(\mu_{3}-\mathrm{O}\right)\right]^{2+}$ & Electrochemical generation, spectroscopic characterization (UV-vis, EPR) & [52] \\
\hline 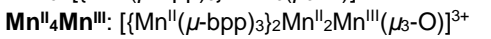 & Chemical synthesis, X-Ray structure, UV-vis., EPR, magnetism & \\
\hline $\mathbf{M n}_{3} \mathbf{M n}_{2} \mathrm{II}_{2}:\left[\left\{\mathrm{Mn}{ }^{\prime \prime}(\mu-\mathrm{bpp})_{3}\right\}_{2} \mathrm{Mn}^{\prime \prime} \mathrm{Mn}^{\prime \prime \prime}{ }_{2}\left(\mu_{3}-\mathrm{O}\right)\right]^{4+}$ & Electrochemical synthesis, X-ray structure, UV-vis., EPR, magnetism & \\
\hline $\mathbf{M n}_{2} \mathbf{M n}^{\prime \prime \prime}{ }_{3}:\left[\left\{\mathrm{Mn}^{\prime \prime}(\mu-\mathrm{bpp})_{3}\right\}_{2} \mathrm{Mn}^{\prime \prime \prime}{ }_{3}\left(\mu_{3}-\mathrm{O}\right)\right]^{5+}$ & Electrochemical generation, UV-vis., EPR & \\
\hline 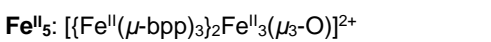 & Chemical and electrochemical synthesis, X-ray structure, UV-vis., Mössbauer, magnetism & {$[61][56,61]$} \\
\hline $\mathrm{Fe}^{\prime \prime}{ }_{4} \mathrm{Fe}^{\prime \prime \prime \prime}:\left[\left\{\mathrm{Fe}^{\prime \prime}(\mu-\mathrm{bpp})_{3}\right\}_{2} \mathrm{Fe}{ }_{2} \mathrm{Fe}^{\text {III }}\left(\mu_{3}-\mathrm{O}\right)\right]^{3+}$ & Chemical synthesis, X-ray structure, UV-vis., Mössbauer & \\
\hline $\mathrm{Fe}_{3}{ }_{3} \mathrm{Fe}^{\prime \prime \prime \prime}{ }_{2}:\left[\left\{\mathrm{Fe}^{\prime \prime}(\mu-\mathrm{bpp})_{3}\right\}_{2} \mathrm{Fe}^{\|} \mathrm{Fe}^{\prime \prime \prime \prime}{ }_{2}\left(\mu_{3}-\mathrm{O}\right)\right]^{4+}$ & Electrochemical generation, UV-vis., Mössbauer & \\
\hline $\mathrm{Fe}^{\prime \prime}{ }_{2} \mathrm{Fe}^{\prime \prime \prime \prime}:\left[\left\{\mathrm{Fe}_{3}^{\prime \prime \prime}(\mu-\mathrm{bpp})_{3}\right\}_{2} \mathrm{Fe}^{\prime \prime}{ }_{2} \mathrm{Fe}^{\prime \prime \prime \prime}\left(\mu_{3}-\mathrm{O}\right)\right]^{5+}$ & Electrochemical synthesis, UV-vis., Mössbauer & \\
\hline $\mathrm{Fe}^{\prime \prime} \mathrm{Fe}^{\prime \prime \prime}{ }_{4}:\left[\left\{\mathrm{Fe}^{\prime \prime \prime}(\mu-\mathrm{bpp})_{3}\right\}_{2} \mathrm{Fe}^{\prime \prime} \mathrm{Fe}^{\prime \prime \prime}{ }_{2}\left(\mu_{3}-\mathrm{O}\right)\right]^{6+}$ & Electrochemical synthesis, UV-vis., Mössbauer & \\
\hline Co'Co"l $_{4}:\left[\left\{\mathrm{Co}{ }^{\prime \prime}(\mu-\mathrm{bpp})_{3}\right\}_{2} \mathrm{Co}^{\prime} \mathrm{Co}{ }_{2}{ }_{2}\left(\mu_{3} \mathrm{OH}\right)\right]^{2+}$ & Electrochemical synthesis, X-ray structure, UV-vis. EPR, magnetism & [53-54] \\
\hline $\mathrm{Co}_{5}{ }_{5}:\left[\left\{\mathrm{Co}^{\prime \prime}(\mu-\mathrm{bpp})_{3}\right\}_{2} \mathrm{Co}_{3}{ }_{3}\left(\mu_{3}-\mathrm{OH}\right)\right]^{2+}$ & Chemical synthesis, $\mathrm{X}$-ray structure, UV-vis., EPR, magnetism & \\
\hline $\mathrm{Co}_{3} \mathrm{Co}_{2}{ }^{\prime \prime \prime}:\left[\left\{\mathrm{Co}{ }^{\prime \prime}(\mu-\mathrm{bpp})_{3}\right\}_{2} \mathrm{Co}^{\prime \prime} \mathrm{Co}^{\prime \prime \prime}{ }_{2}\left(\mu_{3}-\mathrm{OH}\right)\right]^{5+}$ & Electrochemical synthesis, X-ray structure, UV-vis. EPR, magnetism & \\
\hline $\mathbf{Z n}^{\prime \prime}:\left[\left\{\mathbf{Z n}^{\prime \prime}(\mu-\mathrm{bpp})_{3}\right\}_{2} \mathbf{Z n}^{\prime \prime}{ }_{3}\left(\mu_{3}-\mathrm{OH}\right)\right]^{2+}$ & Chemical synthesis, X-ray structure, UV-vis. & {$[51,53]$} \\
\hline $\mathbf{C u}_{5}:\left[\left\{\mathrm{Cu}^{\prime \prime}(\mu-\mathrm{bpp})_{3}\right\}_{2} \mathrm{Cu}_{3}{ }_{3}\left(\mu_{3}-\mathrm{OH}\right)\right]^{2+}$ & Chemical synthesis, X-ray structure, magnetism & {$[50]$} \\
\hline $\mathrm{Ni}^{\prime} \mathrm{Ni}_{4}:\left[\left\{\mathrm{Ni}^{\prime \prime}(\mu-\mathrm{bpp})_{3}\right\}_{2} \mathrm{Ni}^{\prime} \mathrm{Ni}^{\prime \prime}\left(\mu_{3}-\mathrm{OH}\right)\right]^{2+}$ & Electrochemical synthesis, X-ray structure, UV-vis., EPR & [51] \\
\hline $\mathrm{NiI}_{5}:\left[\left\{\mathrm{Ni}{ }^{\prime \prime}(\mu-\mathrm{bpp})_{3}\right\}_{2} \mathrm{Ni}_{3}{ }_{3}\left(\mu_{3}-\mathrm{OH}\right)\right]^{2+}$ & Chemical synthesis, X-ray structure, UV-vis., EPR & This \\
\hline $\left.\mathrm{Ni}_{4}{ }_{4} \mathrm{Ni}{ }^{\prime \prime \prime}:\left[\mathrm{Ni}^{\prime \prime}(\mu-\mathrm{bpp})_{3}\right\}_{2} \mathrm{Ni}_{2}{ }_{2} \mathrm{Ni}^{\prime \prime \prime}\left(\mu_{3}-\mathrm{OH}\right)\right]^{4+}$ & Electrochemical generation, UV-vis., EPR & work \\
\hline $\left.\mathrm{Ni}_{3} \mathrm{Ni}^{\prime \prime \prime}{ }_{2}:\left[\mathrm{Ni}{ }^{i \prime}(\mu-\mathrm{bpp})_{3}\right\}_{2} \mathrm{Ni}^{\prime \prime} \mathrm{Ni}^{i \prime \prime}{ }_{2}\left(\mu_{3}-\mathrm{OH}\right)\right]^{5+}$ & Electrochemical generation, UV-vis., EPR & \\
\hline
\end{tabular}




\section{Conclusion}

The nickel pentanuclear complex obtained from the binucleating rigid tetradentate ligand 3,5-bis(pyridine-2-yl)pyrazole ligand (bpp-) has been structurally characterized in two distinct redox states: the air stable $\left[\left\{\mathrm{Ni}^{\prime \prime}(\mu \text {-bpp })_{3}\right\}_{2} \mathrm{Ni}_{3}\left(\mu_{3}-\mathrm{OH}\right)\right]^{3+}\left(\mathbf{1}^{3+}\right)$, and the one-electron reduced state, $\left[\left\{\mathrm{Ni}^{\prime \prime}(\mu \text {-bpp })_{3}\right\}_{2} \mathrm{Ni}^{\prime} \mathrm{Ni}_{2}\left(\mu_{3}-\mathrm{OH}\right)\right]^{3+}\left(\mathbf{1}^{2+}\right)$. This complex presents a multireversible redox behavior as previously observed for the $\mathrm{Mn}, \mathrm{Fe}$ and $\mathrm{Co}$ analogous pentanuclear derivatives although each complex possesses a distinct redox behavior. Notably, the cyclic voltammogram of the $\mathrm{Ni}$ complex $\mathbf{1}^{3+}$ exhibits four reversible well-separated oneelectron metal-centered redox processes, two corresponding to oxidation events and two to reduction processes, and hence five consecutive redox states from $\mathrm{Ni}_{2} \mathrm{Nil}_{3}$ to $\mathrm{Ni}_{3}{ }_{3} \mathrm{Ni}^{\prime \prime l}{ }_{2}$ can be stabilized. A third oxidation wave corresponding to $\mathrm{Ni}_{3}{ }_{3} \mathrm{Ni}^{\prime \prime \prime}{ }_{2}$ into $\mathrm{Ni}_{2} \mathrm{Ni}{ }_{3}$ located at high positive potential appears quasireversible. The quantitative generation by successive bulk electrolyses of the two one-electron oxidized species $\mathrm{Ni}_{4}{ }_{4} \mathrm{Ni}^{\mathrm{III}}$ and $\mathrm{Ni}_{3}{ }_{3} \mathrm{Ni}^{i{ }_{2}}$, as well as the one-electron reduced species, $\mathrm{Ni}^{\prime} \mathrm{Ni}_{4}{ }_{4}$, shows once again that the constrained structure of these compounds allows them to be stabilized in a number of different redox states, without structural change, ranging from reduced $\mathrm{Ni}(\mathrm{I})$ to oxidized $\mathrm{Ni}(\mathrm{III})$ states. Such stability had already been observed for the analogous cobalt complex although its electrochemical behavior is not totally equivalent. Finally, the oneelectron reduced species, $\mathrm{Ni}^{\prime} \mathrm{Ni}^{\prime \prime}$, structurally characterized, is the first illustration of a mixed-valence hydroxo-centered $\left\{\mathrm{Ni}^{\prime} \mathrm{Ni}_{2}{ }_{2}\left(\mu_{3}-\right.\right.$ $\mathrm{OH})\}^{4+}$ trinuclear unit, $i$. e. with one $\mathrm{Ni}$ ions at the $+\mathrm{l}$ oxidation state. In future works, we will explore the possibility to access heterobimetallic compounds presenting the same bis(triple)helicate architecture by introducing a different metal in the apical and central positions.

\section{Experimental Section}

\section{Synthesis of the complexes.}

Caution! Perchlorate salts of compounds containing organic ligands are potentially explosive. Although we have encountered no such problems, only small quantities of these compounds should be prepared and handled with care.

Synthesis of $\left[\left\{\mathrm{Nil}^{\prime \prime}(\mu-\mathrm{bpp})_{3}\right\}_{2} \mathrm{Nil}_{3}\left(\mu_{3}-\mathrm{OH}\right)\right]\left(\mathrm{BF}_{4}\right)_{3} \quad\left(\mathbf{1}^{3+}\right)$. A solution of $\mathrm{Ni}\left(\mathrm{BF}_{4}\right)_{2} \cdot 6 \mathrm{H}_{2} \mathrm{O}(128 \mathrm{mg}, 0.375 \mathrm{mmol})$ in acetonitrile $(6 \mathrm{~mL})$ was added to a stirred acetonitrile $(16 \mathrm{~mL})$ solution of Hbpp $(100 \mathrm{mg}, 0.45 \mathrm{mmol})$ and $\mathrm{Et}_{3} \mathrm{~N}(156 \mu \mathrm{L}, 1.12 \mathrm{mmol})$ in a $150 \mathrm{~mL}$ glass tube sealed by a Teflon cap leading to a blue solution with a solid in suspension. The reaction mixture was heated at $120^{\circ} \mathrm{C}$ during 3 days leading to a green solution with a small amount of a brownish precipitate. The resulting mixture was then cooled to room temperature, filtered to remove some insoluble white/brown solid. The green filtrate containing $\left[\left\{\mathrm{Ni}^{\prime \prime}(\mu-\mathrm{bpp})_{3}\right\}_{2} \mathrm{Ni}_{3}{ }_{3}\left(\mu_{3}-\mathrm{OH}\right)\right]\left(\mathrm{BF}_{4}\right)_{3}$ in acetonitrile was concentrated with a rotating evaporator until ca. $8 \mathrm{~mL}$, and diethyl ether was added by slow vapor diffusion affording green crystals of the expected Ni pentanuclear complex. The crystals were then filtrated off, washed with diethyl ether and dry under vacuum (128 mg, yield $90 \%)$. IR $\left(\mathrm{cm}^{-1}\right): 3618(w), 3503(\mathrm{w}), 3122(\mathrm{w}), 3091(\mathrm{w}), 1604(\mathrm{~s}), 1565(\mathrm{w}), 1539$ (w), $1460(\mathrm{~m}), 1436(\mathrm{~s}), 1339(\mathrm{~m}), 12574(\mathrm{~m}), 1226(\mathrm{w}), 1159(\mathrm{w}), 1045$ (vs), $969(\mathrm{~m}), 895(\mathrm{w}), 773(\mathrm{~s}), 738(\mathrm{~m}), 694(\mathrm{w}), 681(\mathrm{w}), 640(\mathrm{w}), 553(\mathrm{w})$ $520(w), 502(w), 479(w), 449(w), 419(\mathrm{~m})$. Elemental analysis calcd $(\%)$ for $\mathrm{C}_{78} \mathrm{H}_{55} \mathrm{~B}_{3} \mathrm{Ni}_{5} \mathrm{~F}_{12} \mathrm{~N}_{24} \mathrm{O} \cdot 4 \mathrm{H}_{2} \mathrm{O}\left(1970.37 \mathrm{~g} \mathrm{~mol}^{-1}\right)$ : C, 47.55; $\mathrm{H}, 3.22 ; \mathrm{N}$ 17.06. Found: $\mathrm{C}, 47.25 ; \mathrm{H}, 3.21 ; \mathrm{N}, 17.05$

$10 \mathrm{mg}$ of the green crystals of $\left[\left\{\mathrm{Ni}^{\prime \prime}(\mu \text {-bpp })_{3}\right\}_{2} \mathrm{Ni}_{3}{ }_{3}\left(\mu_{3}-\mathrm{OH}\right)\right]\left(\mathrm{BF}_{4}\right)_{3}$ were redissolved in acetonitrile $(6 \mathrm{~mL})$ containing $0.05 \mathrm{M}$ of $\left[\mathrm{Bu}_{4} \mathrm{~N}\right] \mathrm{ClO}_{4}$. Single crystals of $\left[\left\{\mathrm{Nil}^{\prime \prime}(\mu \text {-bpp })_{3}\right\}_{2} \mathrm{Ni}^{\prime \prime}{ }_{3}\left(\mu_{3}-\mathrm{OH}\right)\right]\left(\mathrm{ClO}_{4}\right)_{3} \cdot 1.5 \mathrm{CH}_{3} \mathrm{CN} \cdot\left(\mathrm{CH}_{3} \mathrm{CH}_{2}\right)_{2} \mathrm{O}$ were grown by slow diffusion of diethyl ether into this solution $(9 \mathrm{mg}$, yield $82 \%)$.

Electrochemical synthesis of $\left[\left\{\mathrm{Ni}^{\prime \prime}(\mu-b p p)_{3}\right\}_{2} \mathrm{Ni}^{\prime} \mathrm{Ni}_{2}\left(\mu_{3}-\mathrm{OH}\right)\right]\left(\mathrm{ClO}_{4}\right)_{2}\left(\mathbf{1}^{2+}\right)$. A solution of $1\left(\mathrm{BF}_{4}\right)_{3}(13 \mathrm{mg})$ in acetonitrile $(5 \mathrm{~mL})$ containing $0.1 \mathrm{M}$ of $\left[\mathrm{Bu}_{4} \mathrm{~N}\right] \mathrm{ClO}_{4}$ was reduced at $-1.70 \mathrm{~V}$ vs $\mathrm{Ag} / \mathrm{AgNO}_{3}$ on a reticulated vitreous carbon electrode in glove box under argon atmosphere. After exhaustive electrolysis (one electron exchanged per molecule of initial complex), the formation of $\left[\left\{\mathrm{Ni}^{\prime \prime}(\mu-\mathrm{bpp}){ }_{3}\right\}_{2} \mathrm{Ni}^{\prime} \mathrm{Ni}^{\mathrm{Il}}{ }_{2}(\mu-\mathrm{OH})\right]^{2+}\left(\mathbf{1}^{2+}\right)$ is controlled by cyclic voltammetry and UV-visible spectroscopy. The dark grey solution is then filtered to remove the carbon residue. Dark grey single crystals of $1\left(\mathrm{ClO}_{4}\right)_{2} \cdot 2.5 \mathrm{CH}_{3} \mathrm{CN}$ were obtained by slow vapor diffusion of diethylether into the electrogenerated solution under argon atmosphere (yield: $10 \mathrm{mg}$, $77 \%$ )

CCDC 2086376 and 2086378 contain the supplementary crystallographic data for this paper. These data can be obtained free of charge via www.ccdc.cam.ac.uk/data request/cif, or by emailing data_request@ccdc.cam.ac.uk, or by contacting The Cambridge Crystallographic Data Centre, 12 Union Road, Cambridge CB2 1EZ, UK; fax: +44 1223336033

\section{Acknowledgements}

This work has been partially supported by the French National Research Agency through Labex ARCANE and CBH-EUR-GS (ANR-17-EURE-0003) for the project MnCaPSII, as well as ANR 13-BS07-0015-01 (MnCaOEC) including the E.G. postdoctoral grant. B.G. thanks the "Université Grenoble Alpes" for his PhD grant. We thank the IR-RPE CNRS FR3443 RENARD network for EPR facilities. The NanoBio-ICMG platforms (FR 2607) are acknowledged for their support. This work was also supported by COST CM1202 program (PERSPECT $\mathrm{H}_{2} \mathrm{O}$ )

Keywords: Mixed-valence state $\bullet$ low-valent nickel (I) $•$ pyrazole ligand $\bullet$ helical structures $\cdot$ reversible system

[1] J.-M. Lehn, Chem. Soc. Rev. 2007, 36, 151-160.

[2] Y. E. Alexeev, B. I. Kharisov, T. C. H. García, A. D. Garnovskii, Coord. Chem. Rev. 2010, 254, 794-831.

[3] S. Leininger, B. Olenyuk, P. J. Stang, Chem. Rev. 2000, 100, 853-908.

[4] H. Miyake, H. Tsukube, Chem. Soc. Rev. 2012, 41, 6977-6991.

[5] G. E. Kostakis, S. P. Perlepes, V. A. Blatov, D. M. Proserpio, A. K. Powell, Coord. Chem. Rev. 2012, 256, 1246-1278.

[6] K. Griffiths, V. A. Blatov, G. E. Kostakis, in Single - Molecule Magnets, 2018, pp. 353-388.

[7] R. Bagai, G. Christou, Chem. Soc. Rev. 2009, 38, 1011-1026.

[8] G. Maayan, N. Gluz, G. Christou, Nature Catalysis 2018, 1, 48-54.

[9] A. M. Kirillov, M. V. Kirillova, A. J. L. Pombeiro, Coord. Chem. Rev. 2012, 256, 2741-2759.

[10] D. S. Nesterov, O. V. Nesterova, A. J. L. Pombeiro, Coord. Chem. Rev. 2018, 355, 199-222.

[11] D. S. Nesterov, O. V. Nesterova, Catalysts 2018, 8, 602

[12] B. Gerey, E. Gouré, J. Fortage, J. Pécaut, M.-N. Collomb, Coord. Chem. Rev. 2016, 319, 1-24.

[13] E. Salvadeo, L. Dubois, J.-M. Latour, Coord. Chem. Rev. 2018, 374, 345-375.

[14] J.-F. Capon, F. Gloaguen, F. Y. Petillon, P. Schollhammer, J. Talarmin, Coord. Chem. Rev. 2009, 253, 1476-1494.

[15] B. Battistella, K. Ray, Coord. Chem. Rev. 2020, 408, 213176.

[16] T. Shiga, G. N. Newton, H. Oshio, Dalton Trans. 2018, 47, 7384-7394.

[17] G. N. Newton, T. Onuki, T. Shiga, M. Noguchi, T. Matsumoto, J. S. Mathieson, M. Nihei, M. Nakano, L. Cronin, H. Oshio, Angew. Chem. Int. Ed. 2011, 50, 4844-4848.

[18] J. G. Haasnoot, Coord. Chem. Rev. 2000, 200-202, 131-185

[19] U. Beckmann, S. Brooker, Coord. Chem. Rev. 2003, 245, 17-29.

[20] M. H. Klingele, S. Brooker, Coord. Chem. Rev. 2003, 241, 119-132

[21] J. Klingele, S. Dechert, F. Meyer, Coord. Chem. Rev. 2009, 253, 26982741

[22] M. Viciano-Chumillas, S. Tanase, L. J. de Jongh, J. Reedijk, Eur. J. Inorg. Chem. 2010, 3403-3418.

[23] J. Garcia-Anton, R. Bofill, L. Escriche, A. Llobet, X. Sala, Eur. J. Inorg. Chem. 2012, 4775-4789.

[24] C. Sens, I. Romero, M. Rodriguez, A. Llobet, T. Parella, J. BenetBuchholz, J. Am. Chem. Soc. 2004, 126, 7798-7799. 
[25] F. Bozoglian, S. Romain, M. Z. Ertem, T. K. Todorova, C. Sens, J. Mola, M. Rodriguez, I. Romero, J. Benet-Buchholz, X. Fontrodona, C. J. Cramer, L. Gagliardi, A. Llobet, J. Am. Chem. Soc. 2009, 131, 15176-15187.

[26] N. Planas, G. J. Christian, E. Mas-Marza, X. Sala, X. Fontrodona, F. Maseras, A. Llobet, Chem. Eur. J. 2010, 16, 7965-7968.

[27] J. Casabó, J. Pons, K. S. Siddiqi, F. Teixidor, E. Molins, C. Miravitlles, J. Chem. Soc., Dalton Trans. 1989, 1401-1403.

[28] J. Pons, X. López, E. Benet, J. Casabó, F. Teixidor, F. J. Sánchez, Polyhedron 1990, 9, 2839-2845.

[29] J. Pons, X. López, J. Casabó, F. Teixidor, A. Caubet, J. Rius, C. Miravitlles, Inorg. Chim. Acta 1992, 195, 61-66.

[30] J. Pons, F. J. Sanchez, A. Labarta, J. Casabo, F. Teixidor, A. Caubet, Inorg. Chim. Acta 1993, 208, 167-171.

[31] M. Munakata, L. P. Wu, M. Yamamoto, T. KurodaSowa, M. Maekawa, S. Kawata, S. Kitagawa, J. Chem. Soc., Dalton Trans. 1995, 40994106.

[32] K. Nakano, N. Suemura, S. Kawata, A. Fuyuhiro, T. Yagi, S. Nasu, S. Morimoto, S. Kaizaki, Dalton Trans. 2004, 982-988.

[33] K. Nakano, S. Kawata, K. Yoneda, A. Fuyuhiro, T. Yagi, S. Nasu, S. Morimoto, S. Kaizaki, Chem. Commun. 2004, 2892-2893.

[34] K. Yoneda, K. Nakano, J. Fujioka, K. Yamada, T. Suzuki, A. Fuyuhiro, S. Kawata, S. Kaizaki, Polyhedron 2005, 24, 2437-2442.

[35] M. Du, S.-T. Chen, Y.-M. Guo, X.-H. Bu, J. Ribas, J. Mol. Struct. 2005 737, 17-21.

[36] K. Yoneda, K. Adachi, S. Hayami, Y. Maeda, M. Katada, A. Fuyuhiro, S. Kawata, S. Kaizaki, Chem. Commun. 2006, 45-47.

[37] R. Ishikawa, A. Fuyuhiro, S. Hayami, K. Inoue, S. Kawata, J. Mol. Struct. 2008, 892, 220-224.

[38] C. Di Giovanni, C. Gimbert-Suriñach, M. Nippe, J. Benet-Buchholz, J. R. Long, X. Sala, A. Llobet, Chem. Eur. J. 2016, 22, 361-369.

[39] C. Gimbert-Surinach, D. Moonshiram, L. Francas, N. Planas, V Bernales, F. Bozoglian, A. Guda, L. Mognon, I. Lopez, M. A. Hoque, L. Gagliardi, C. J. Cramer, A. Llobet, J. Am. Chem. Soc. 2016, 138, 15291-15294.

[40] S. Fukuzumi, S. Mandal, K. Mase, K. Ohkubo, H. Park, J. BenetBuchholz, W. Nam, A. Llobet, J. Am. Chem. Soc. 2012, 134, 99069909.

[41] S. Mandal, S. Shikano, Y. Yamada, Y.-M. Lee, W. Nam, A. Llobet, S. Fukuzumi, J. Am. Chem. Soc. 2013, 135, 15294-15297.

[42] K. Ni-iya, A. Fuyuhiro, T. Yagi, S. Nasu, K. Kuzushita, S. Morimoto, S. Kaizaki, Bull. Chem. Soc. Jpn. 2001, 74, 1891-1897.

[43] Y. Kawamura, Y. Tsukahara, S. Nasu, S. Morimoto, A. Fuyuhiro, S. Kaizaki, Inorg. Chim. Acta 2004, 357, 2437-2440.

[44] R. Kawahata, T. Tsukuda, T. Yagi, A. Subhan, H. Nakata, A. Fuyuhiro, S. Kaizaki, Chem. Lett. 2003, 32, 1084-1085.

[45] R. Kawahata, T. Tsukuda, T. Yagi, A. Fuyuhiro, S. Kaizaki, J. Alloys Compd. 2006, 408, 976-980.

[46] A. Morioka-Yonezawa, N. Sakagami-Yoshida, A. Fuyuhiro, S. Kaizaki Inorg. Chim. Acta 2008, 361, 3623-3630.

[47] L. Mognon, S. Mandal, C. E. Castillo, J. Fortage, F. Molton, G. Aromi, J. Benet-Buchhlolz, M.-N. Collomb, A. Llobet, Chem. Sci. 2016, 7, 3304 3312.

[48] H. Izu, M. Kondo, Y. Saga, H. Iwami, S. Masaoka, Chem. Lett. 2020, 49, 125-128.

[49] K. Yoneda, K. Adachi, K. Nishio, M. Yamasaki, A. Fuyuhiro, M. Katada, S. Kaizaki, S. Kawata, Angew. Chem., Int. Ed. Engl. 2006, 45, 54595461.

[50] R. Ishikawa, M. Nakano, A. Fuyuhiro, T. Takeuchi, S. Kimura, T. Kashiwagi, M. Hagiwara, K. Kindo, S. Kaizaki, S. Kawata, Chem. Eur. J. 2010, 16, 11139-11144.

[51] J. Z. Hou, M. Li, Z. Li, S. Z. Zhan, X. C. Huang, D. Li, Angew. Chem., Int. Ed. Engl. 2008, 47, 1711-1714.

[52] S. Romain, J. Rich, C. Sens, T. Stoll, J. Benet-Buchholz, A. Llobet, M. Rodriguez, I. Romero, R. Clerac, C. Mathoniere, C. Duboc, A. Deronzier, M.-N. Collomb, Inorg. Chem. 2011, 50, 8427-8436.

[53] T. Akai, M. Kondo, S. K. Lee, H. Izu, T. Enomoto, M. Okamura, Y. Saga, S. Masaoka, Dalton Trans. 2020, 49, 1384-1387.

[54] E. Gouré, B. Gerey, F. Molton, J. Pécaut, R. Clérac, F. Thomas, J. Fortage, M.-N. Collomb, Inorg. Chem. 2020, 59, 9196-9205.

[55] M. Kondo, S. Masaoka, Acc. Chem. Res. 2020.

[56] M. Okamura, M. Kondo, R. Kuga, Y. Kurashige, T. Yanai, S. Hayami, V. K. K. Praneeth, M. Yoshida, K. Yoneda, S. Kawata, S. Masaoka, Nature 2016, 530, 465-468.

[57] V. K. K. Praneeth, M. Kondo, M. Okamura, T. Akai, H. Izu, S. Masaoka, Chem. Sci. 2019, 10, 4628-4639.

[58] R.-Z. Liao, S. Masaoka, P. E. M. Siegbahn, ACS Catal. 2018, 8, 1167111678.

[59] P. Pelosin, M. Gil-Sepulcre, P. Garrido-Barros, D. Moonshiram, J. Benet-Buchholz, C. Gimbert-Suriñach, A. Llobet, iScience 2020, 23, 101378.

[60] S. Mehrabani, R. Bikas, Z. Zand, Y. Mousazade, S. I. Allakhverdiev, M. M. Najafpour, Int. J. Hydrogen Energy 2020, 45, 17434-17443.

[61] E. Gouré, B. Gerey, M. Clémancey, J. Pécaut, F. Molton, J.-M. Latour, G. Blondin, M.-N. Collomb, Inorg. Chem. 2016, 55, 9178-9186.

[62] V. Krewald, D. A. Pantazis, Dalton Trans. 2016, 45, 18900-18908.
[63] F. Bentiss, M. Lagrenée, H. Vezin, J. P. Wignacourt, E. M. Holt, O. Mentré, J. Phys. Chem. Solids 2004, 65, 701-705.

[64] R. A. Reynolds, W. O. Yu, W. R. Dunham, D. Coucouvanis, Inorg. Chem. 1996, 35, 2721-2722.

[65] A. A. Sidorov, S. M. Deomidov, V. M. Novotortsev, S. E. Nefedov, I. L. Eremenko, Russ. Chem. Bull. 1998, 47, 1237-1238.

[66] A. Escuer, J. Esteban, N. Aliaga-Alcalde, M. Font-Bardia, T. Calvet, O. Roubeau, S. J. Teat, Inorg. Chem. 2010, 49, 2259-2266.

[67] J. Esteban, E. Ruiz, M. Font-Bardia, T. Calvet, A. Escuer, Chem. Eur. J. 2012, 18, 3637-3648

[68] C. Feng, L.-N. Sun, H.-H. Huang, Z.-R. Qu, H. Zhao, J. Cluster Sci. 2016, 27, 63-72

[69] A. Audhya, M. Maity, K. Bhattacharya, R. Clérac, M. Chaudhury, Inorg Chem. 2010, 49, 9026-9035.

[70] A. Audhya, K. Bhattacharya, M. Maity, M. Chaudhury, Inorg. Chem 2010, 49, 5009-5015.

[71] Y.-S. Wei, J.-Q. Shen, P.-Q. Liao, W. Xue, J.-P. Zhang, X.-M. Chen, Dalton Trans. 2016, 45, 4269-4273.

[72] F. Meyer, H. Kozlowski, in Comprehensive Coordination Chemistry II (Eds.: J. A. McCleverty, T. J. Meyer), Pergamon, Oxford, 2003, pp. 247-554.

[73] P. Zimmermann, C. Limberg, J. Am. Chem. Soc. 2017, 139, 42334242.

[74] C. Zarate, H. Yang, M. J. Bezdek, D. Hesk, P. J. Chirik, J. Am. Chem Soc. 2019, 141, 5034-5044.

[75] J. R. Wilson, M. Zeller, N. K. Szymczak, Chem. Commun. 2021, 57, 753-756.

[76] M. Gennari, M. Orio, J. Pecaut, E. Bothe, F. Neese, M.-N. Collomb, C. Duboc, Inorg. Chem. 2011, 50, 3707-3716.

[77] P.-C. Duan, R. A. Schulz, A. Römer, B. E. Van Kuiken, S. Dechert, S. Demeshko, G. E. Cutsail III, S. DeBeer, R. A. Mata, F. Meyer, Angew. Chem. Int. Ed. 2021, 60, 1891-1896.

[78] C.-L. Hsieh, T.-J. Liu, Y. Song, G.-H. Lee, B.-Y. Jin, T.-S. Lin, S.-M. Peng, Dalton Trans. 2019, 48, 9912-9915.

[79] A. Kubica, J. Kowalewski, D. Kruk, M. Odelius, The Journal of Chemical Physics 2013, 138, 064304.

[80] V. Tangoulis, C. P. Raptopoulou, A. Terzis, E. G. Bakalbassis, E. Diamantopoulou, S. P. Perlepes, Inorg. Chem. 1998, 37, 3142-3153.

[81] T. Shiga, M. Noguchi, H. Sato, T. Matsumoto, G. N. Newton, H. Oshio, Dalton Trans. 2013, 42, 16185-16193.

[82] M. Ruben, E. Breuning, J.-P. Gisselbrecht, J.-M. Lehn, Angew. Chem. Int. Ed. 2000, 39, 4139-4142.

[83] M. Ruben, E. Breuning, M. Barboiu, J.-P. Gisselbrecht, J.-M. Lehn, Chem. Eur. J. 2003, 9, 291-299.

[84] H. Sato, L. Miya, K. Mitsumoto, T. Matsumoto, T. Shiga, G. N. Newton, H. Oshio, Inorg. Chem. 2013, 52, 9714-9716.

[85] T. Matsumoto, G. N. Newton, T. Shiga, S. Hayami, Y. Matsui, H. Okamoto, R. Kumai, Y. Murakami, H. Oshio, Nat. Commun. 2014, 5 , 3865.

[86] E. Gouré, B. Gerey, C. N. Astudillo, J. Pécaut, S. Sirach, F. Molton, J. Fortage, M.-N. Collomb, Inorg. Chem. 2021, 60, 7922-7936.

[87] M. Marcaccio, F. Paolucci, C. Paradisi, S. Roffia, C. Fontanesi, L. J. Yellowlees, S. Serroni, S. Campagna, G. Denti, V. Balzani, J. Am. Chem. Soc. 1999, 121, 10081-10091.

[88] M. Soler, W. Wernsdorfer, K. A. Abboud, J. C. Huffman, E. R. Davidson, D. N. Hendrickson, G. Christou, J. Am. Chem. Soc. 2003, 125, 3576-3588. 
Keywords: Nickel, polynuclear complexes, mixed-valence state, nickel(I) supramolecular

\section{Entry for the Table of Contents}

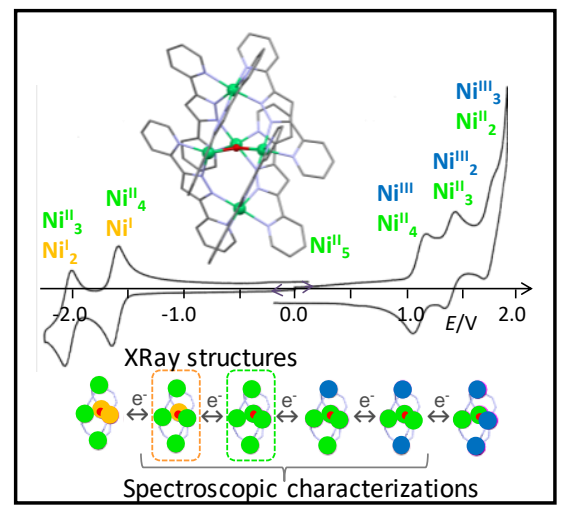

A pentanuclear complex in which to axial $\mathrm{Ni}(\mathrm{II})$ units are connected to a central hydroxo-centered $\mathrm{Ni}(\mathrm{II})_{3}$ trinuclear core through six bridging tetradentate bis-pyridine-pyrazole rigid ligand, can be stabilized in a number of unusual mixed-valence states ranging from $1 \mathrm{Ni}(\mathrm{I}) 4 \mathrm{Ni}(\mathrm{II})$ to $3 \mathrm{Ni}(\mathrm{II}) 2 \mathrm{Ni}(\mathrm{III})$ without structural change. This work highlights the unusual electrochemical behavior of such family of electronically coupled multinuclear complexes.

Institute and/or researcher Twitter usernames: @DCMGrenoble 